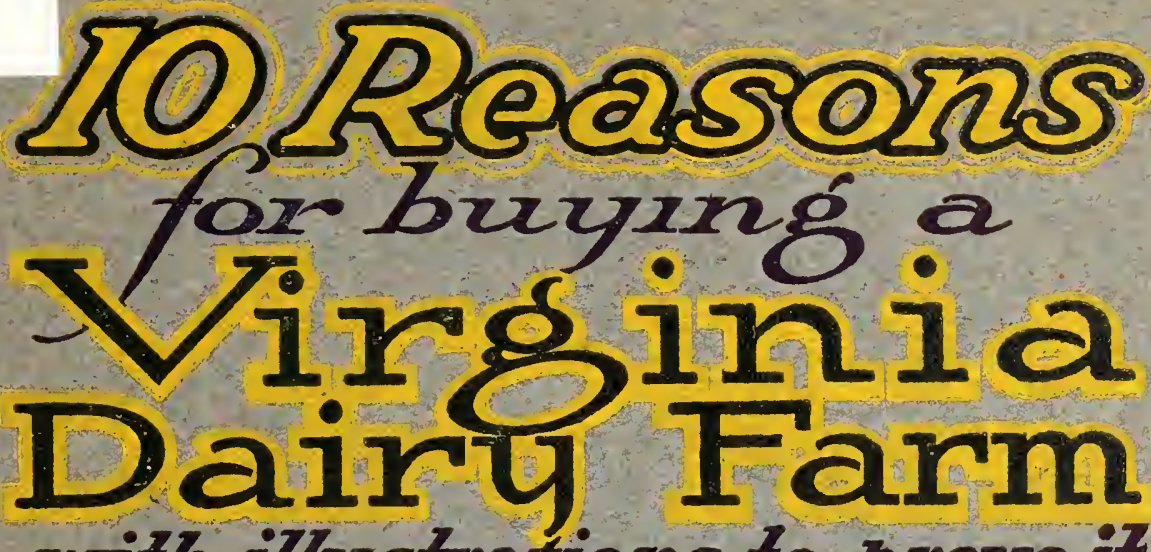
with illustrations to prove it.

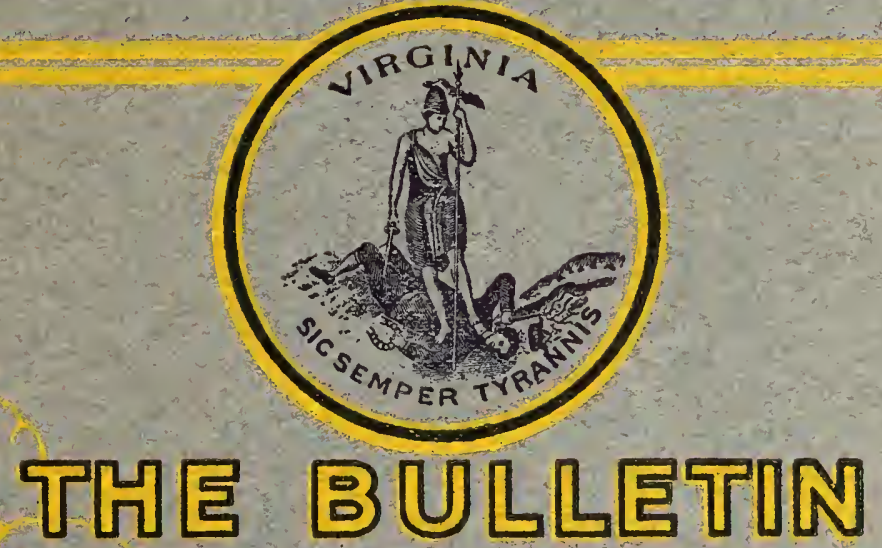
DEPARTMENT OF AGRICULTURE AND IMMIGRATION OF VIRGINIA.

* DAIRY AND FOOD DIVISION

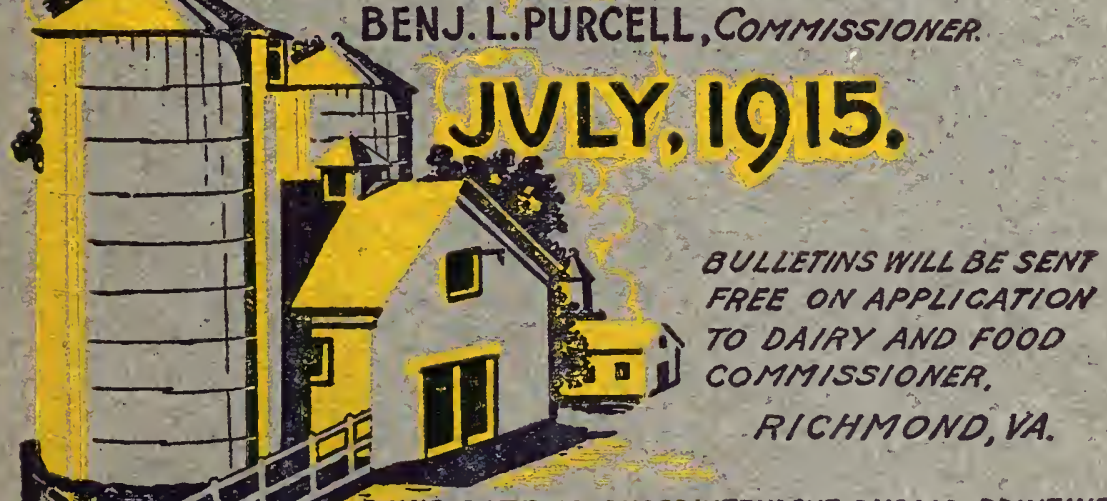





\section{Ten Reasons Why a \\ Dairy Farm In Virginia Pays Better Than In Any Other State : :}




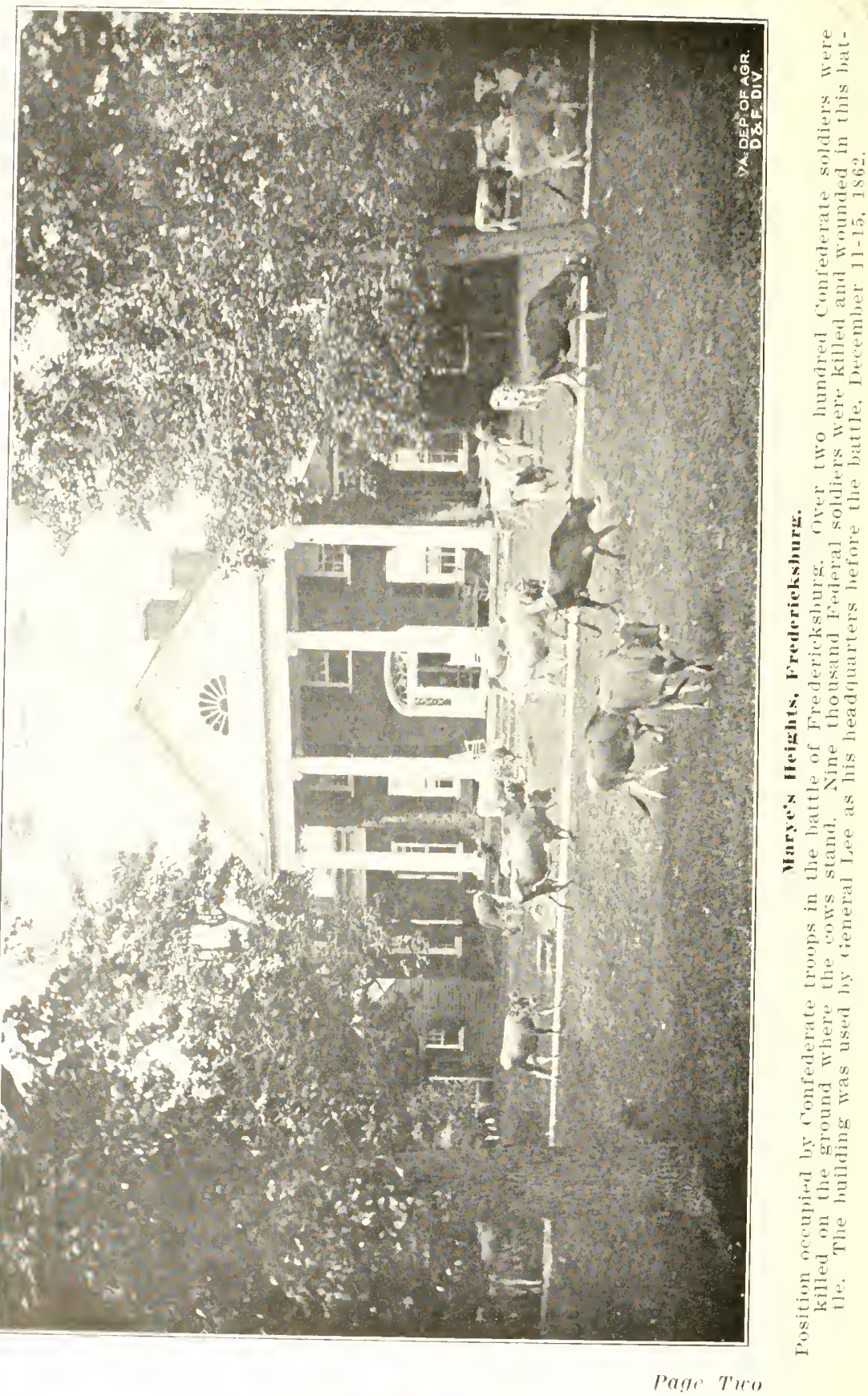

II: 9 


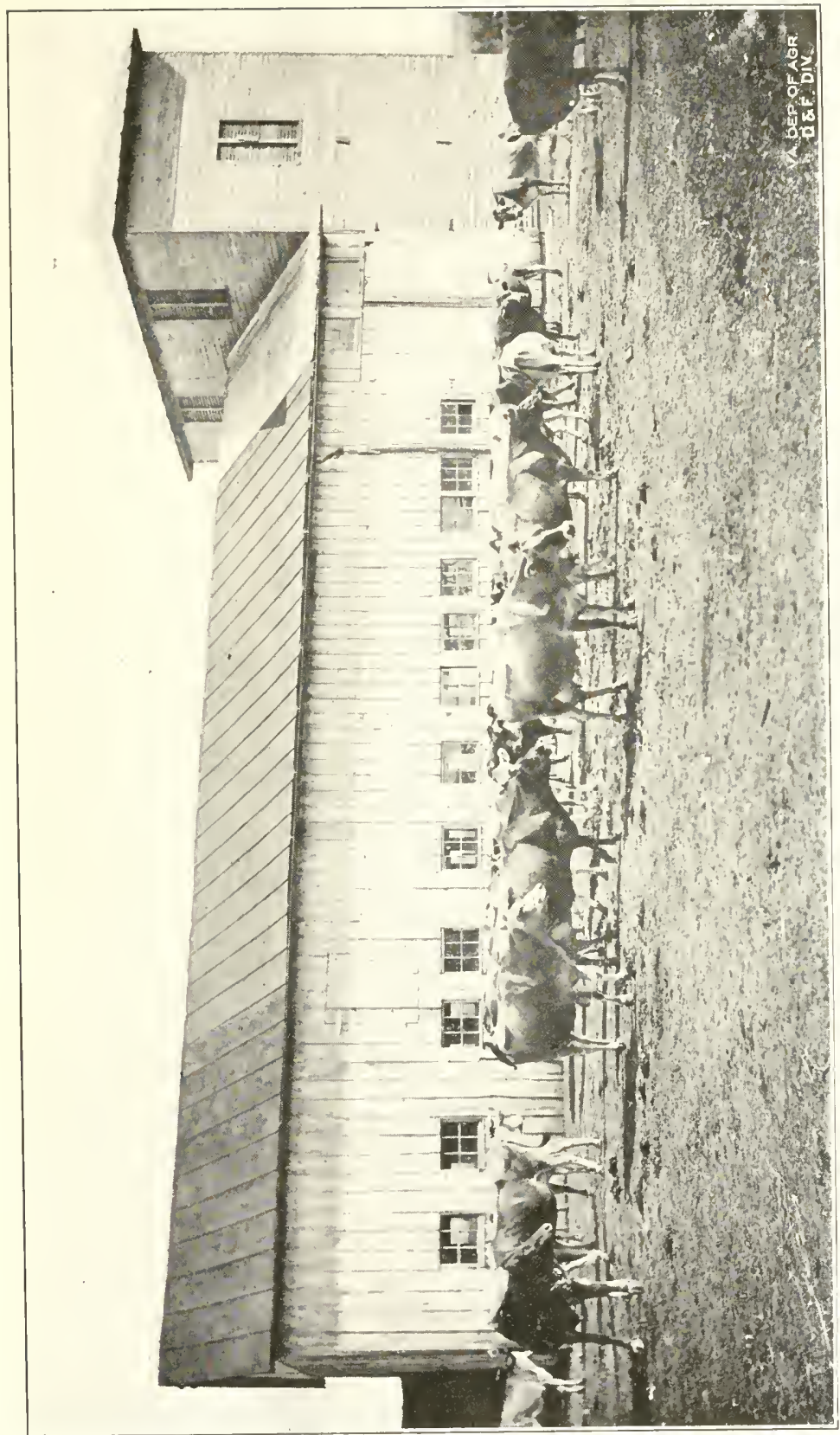

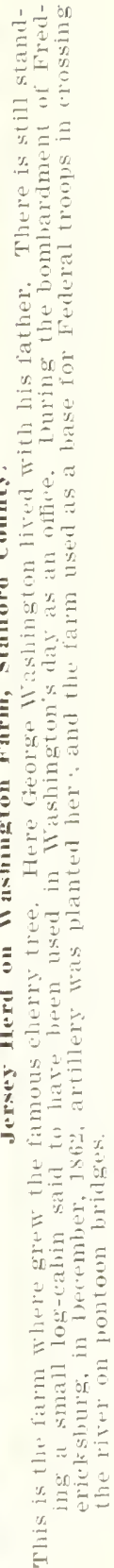




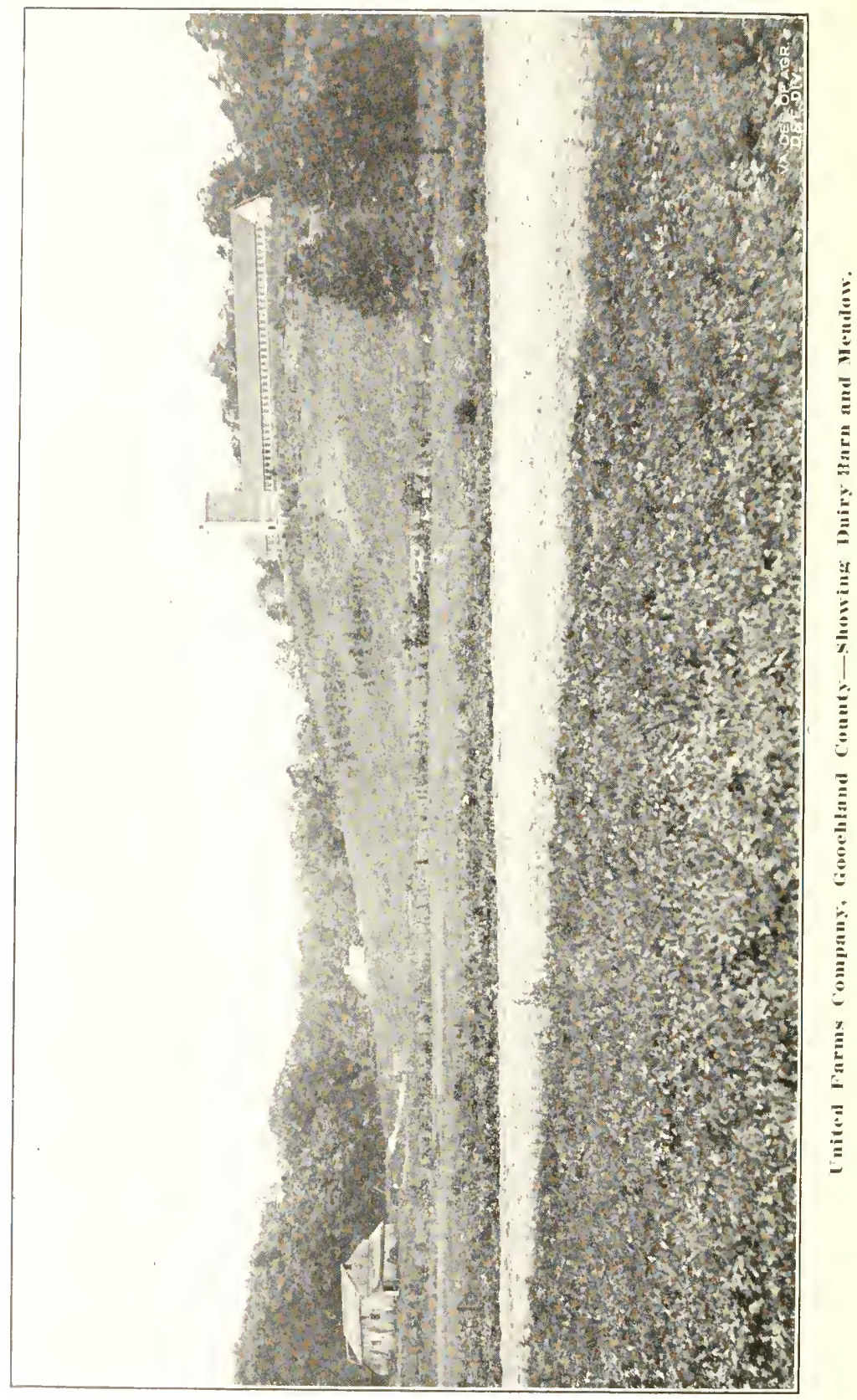

Page Four 


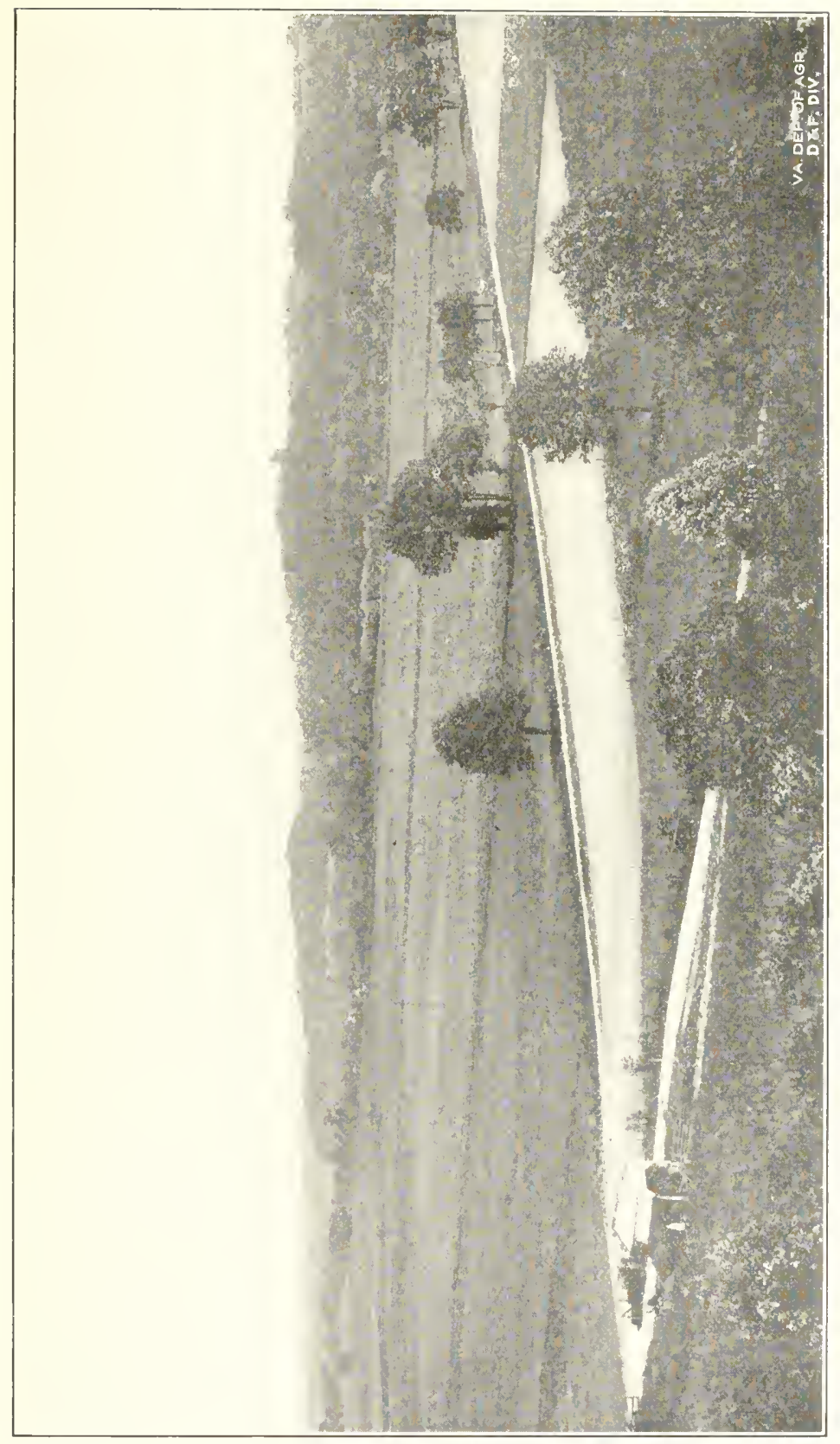

ב⿱

Page Fiv 



\section{Foreword}

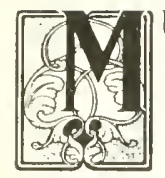

L'C'H has been said and written of the grolor of the old lominion, the mother of States amel statesmen, the home of presirlents, the lambl of romance, the contres of the strugerle which

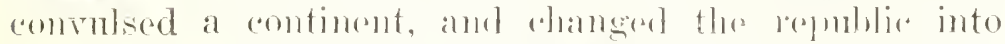
the nation. This phase of Virginial 's gratumes is not onr theme. Wra are witing of the present and fontme.

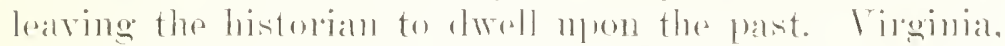

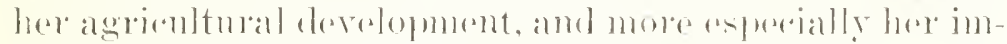

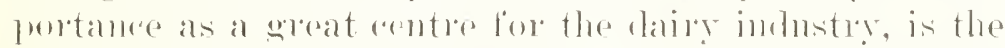

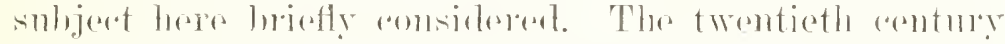
demands that a mam shall find salo and pofitablo insestment in his fanm, togethere with comfort in his home, and rearly aroess to the rontres of polmlation-withont throse artrantages the tremet to the oities is ineritahle. No mon willingly exiles himself form the plobsumes of life, and the time has come when he must have reasomalde assmbander of such business on his falm as shall malko for his immodiate and permonent antrantage, on lo will strive in in-

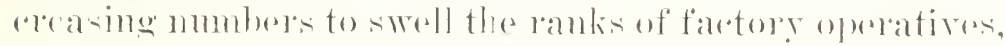
mill hamek, small werke and the host of weary workers who to-ray throme ome aities.

Itith its eastorm bummlaries washerl by the water's of the Itlantie, and its westem highlames jying amone the Pho Ridge and Alloghamy momotains; with its altitmo ranging from 10 to 4.000 feet alhove the lovel of the seat,

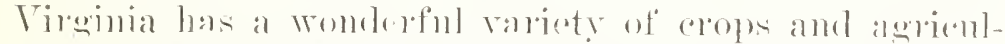

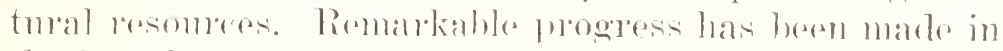
the last few ratris, and the sitate is rapidly developing into one of the foremost agrientura] States of the [Trom. Among the many somress of revenne from the farm, the 


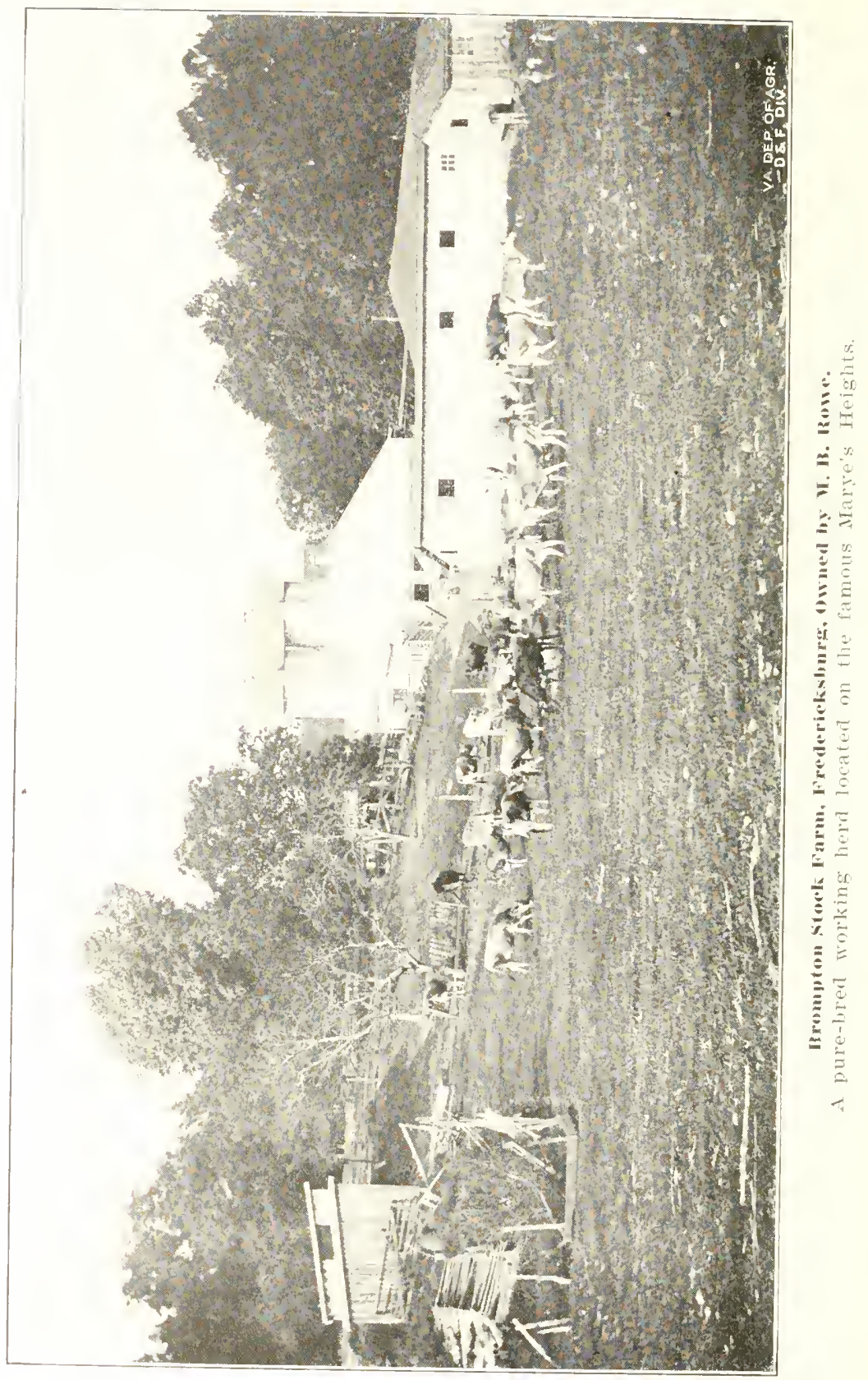

Page Eight 


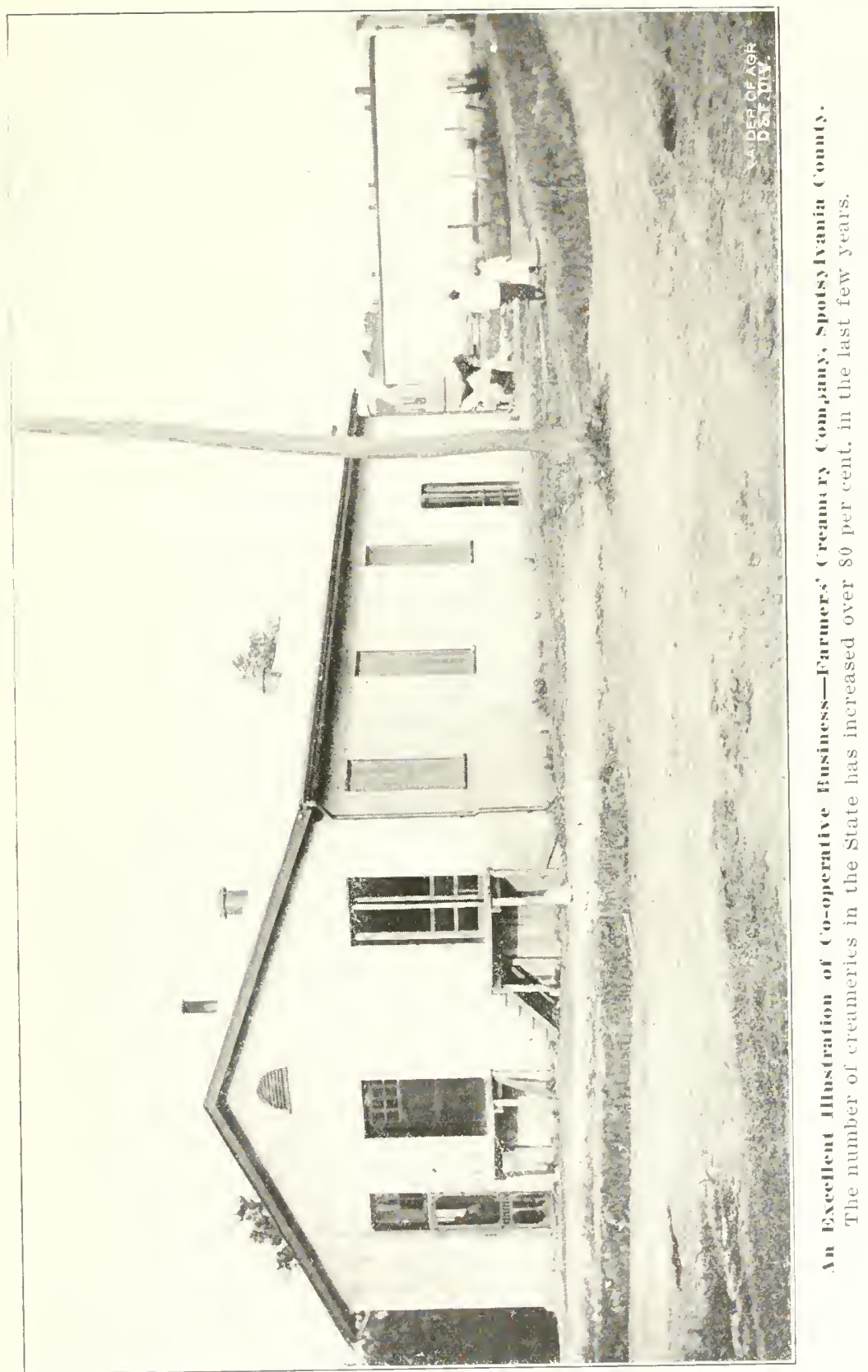

Page Ninte 


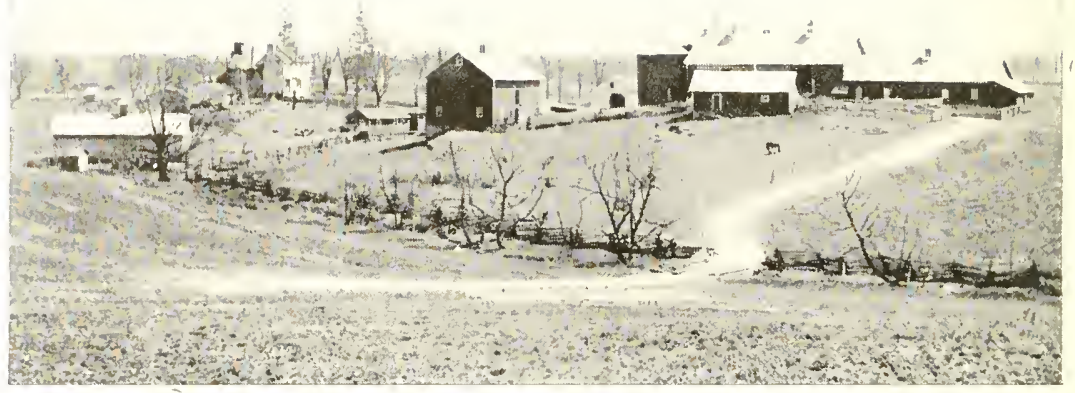

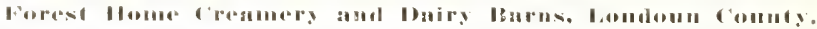

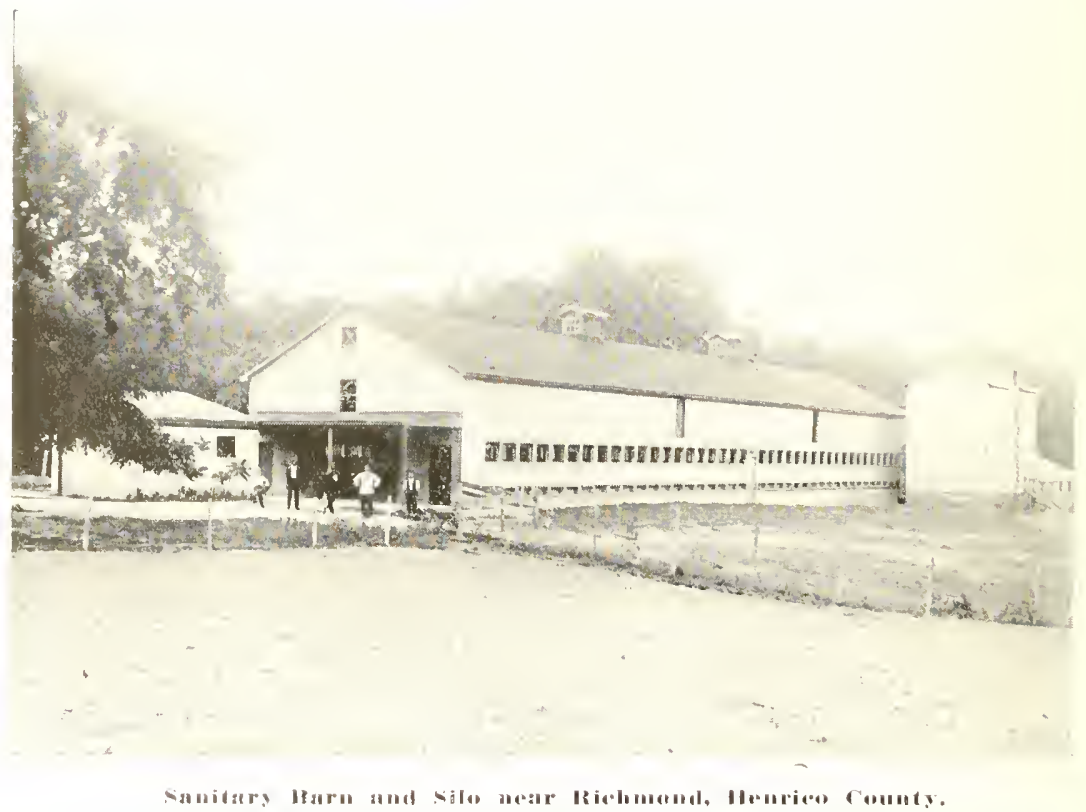

Page Ten 
income from dairving las taken a pominent place. Starting with a few plants, erected mainly for the handling of milk and cream, the number of factories has rapilly increased, until they are now located in practically every section of the State. The production of croam for the manufacture of ies cream, as well as for the making of butter, has increased enormonsly in the last few rours.

Read these ten reasons for owning a Virginia farmthey understate the case-and say, is not life muler these conditions as nearly ideal as one can hope for?

Tnvestigate these farts and then art upon them.

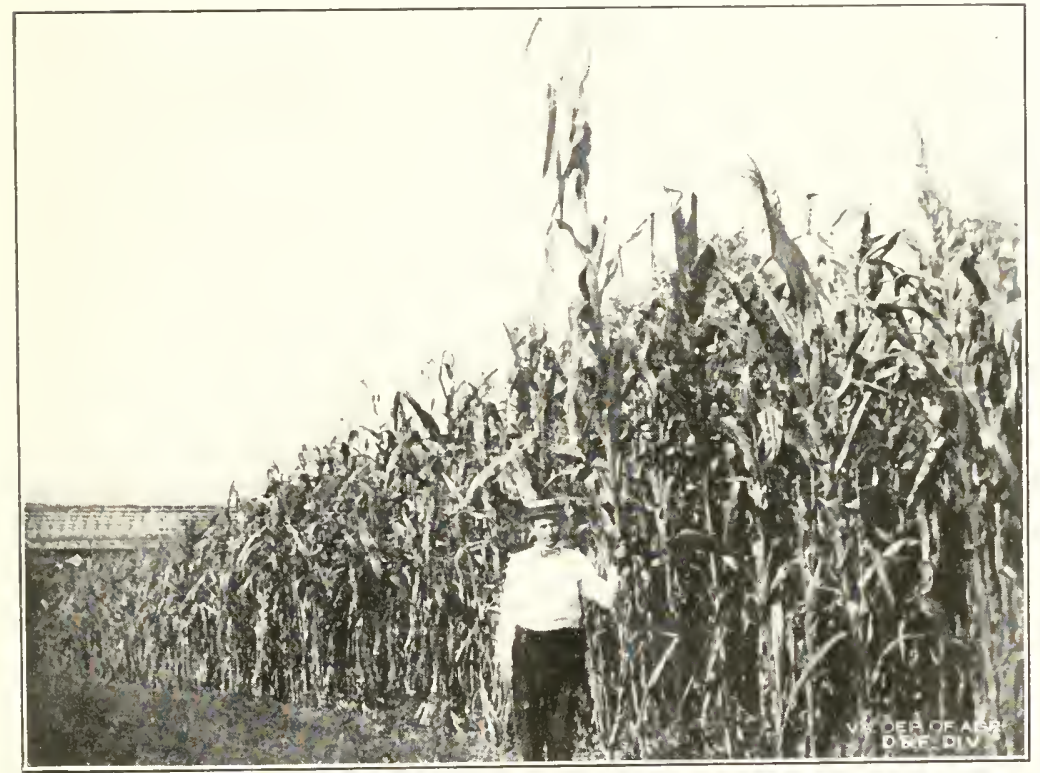

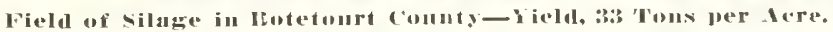




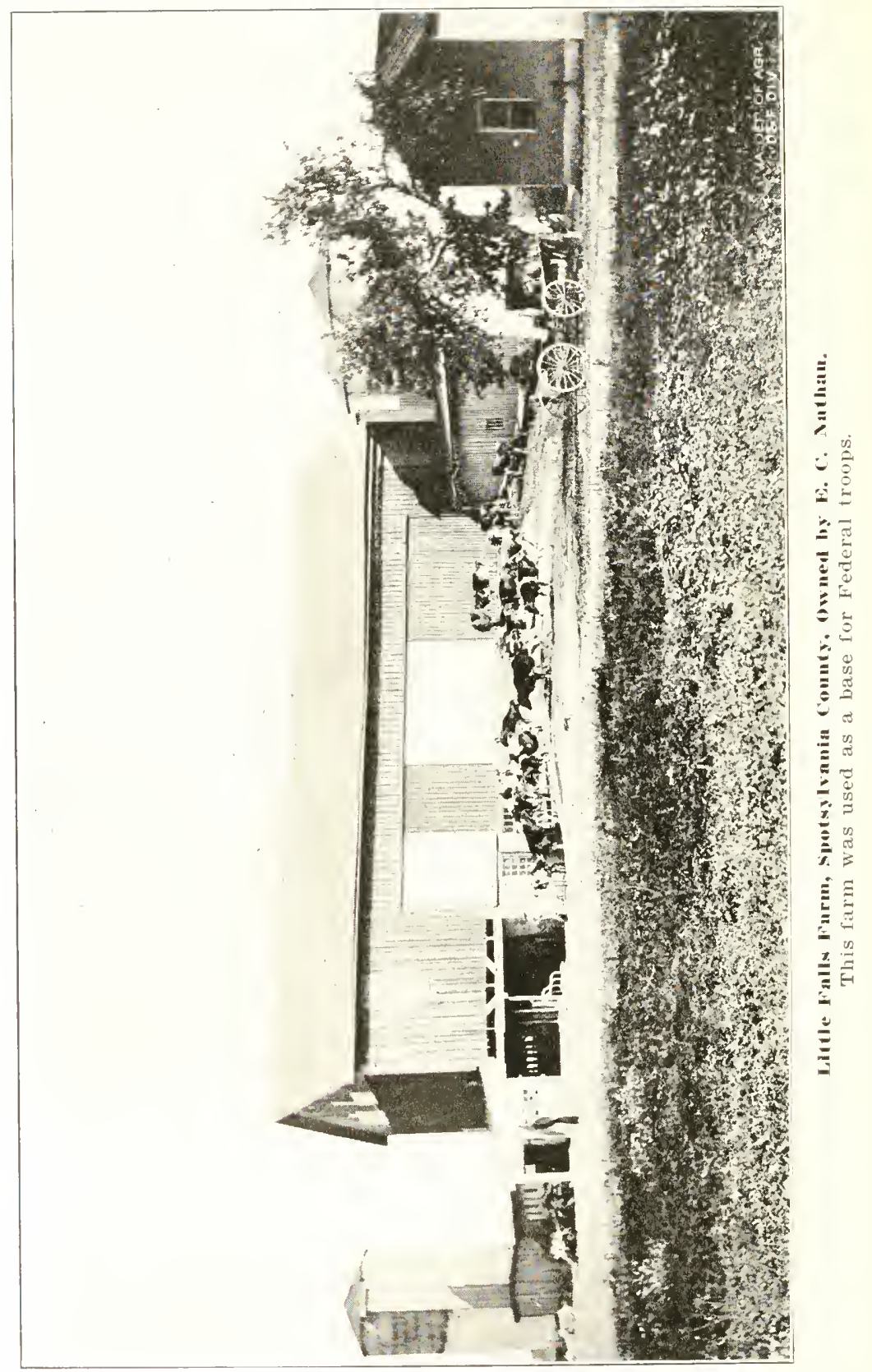

Page Trelve 


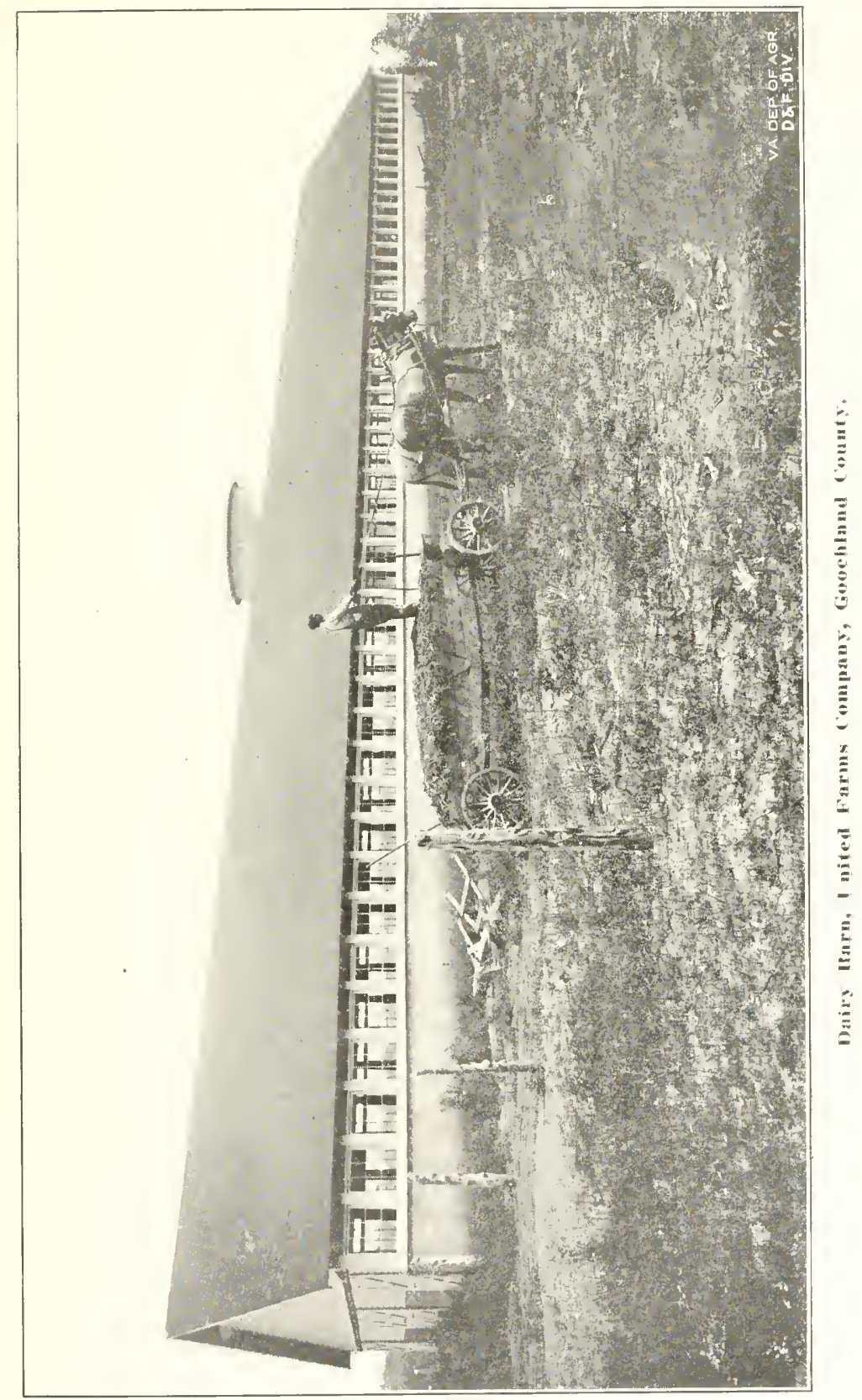

Page Thirteen 


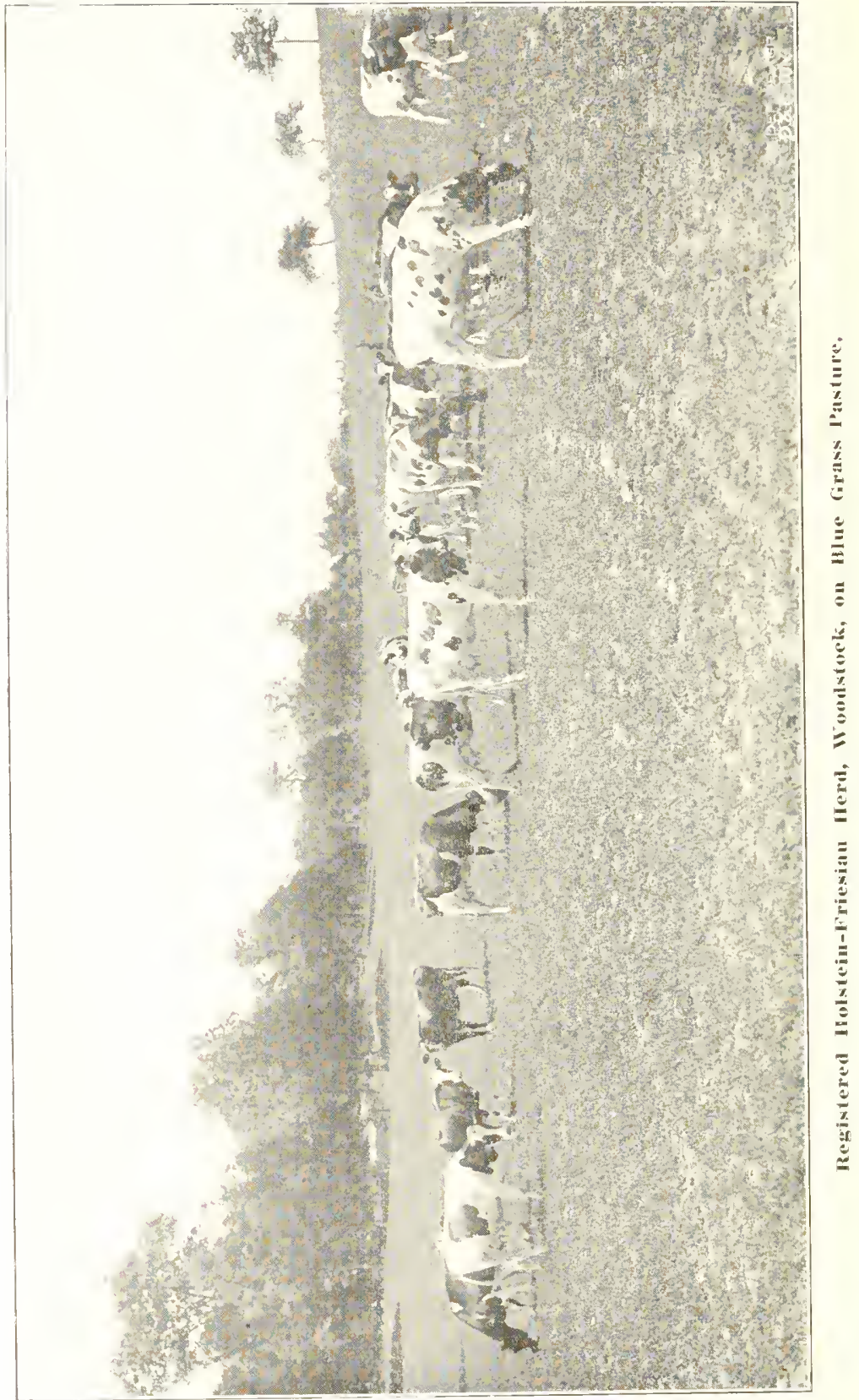

Pues Fourtern 


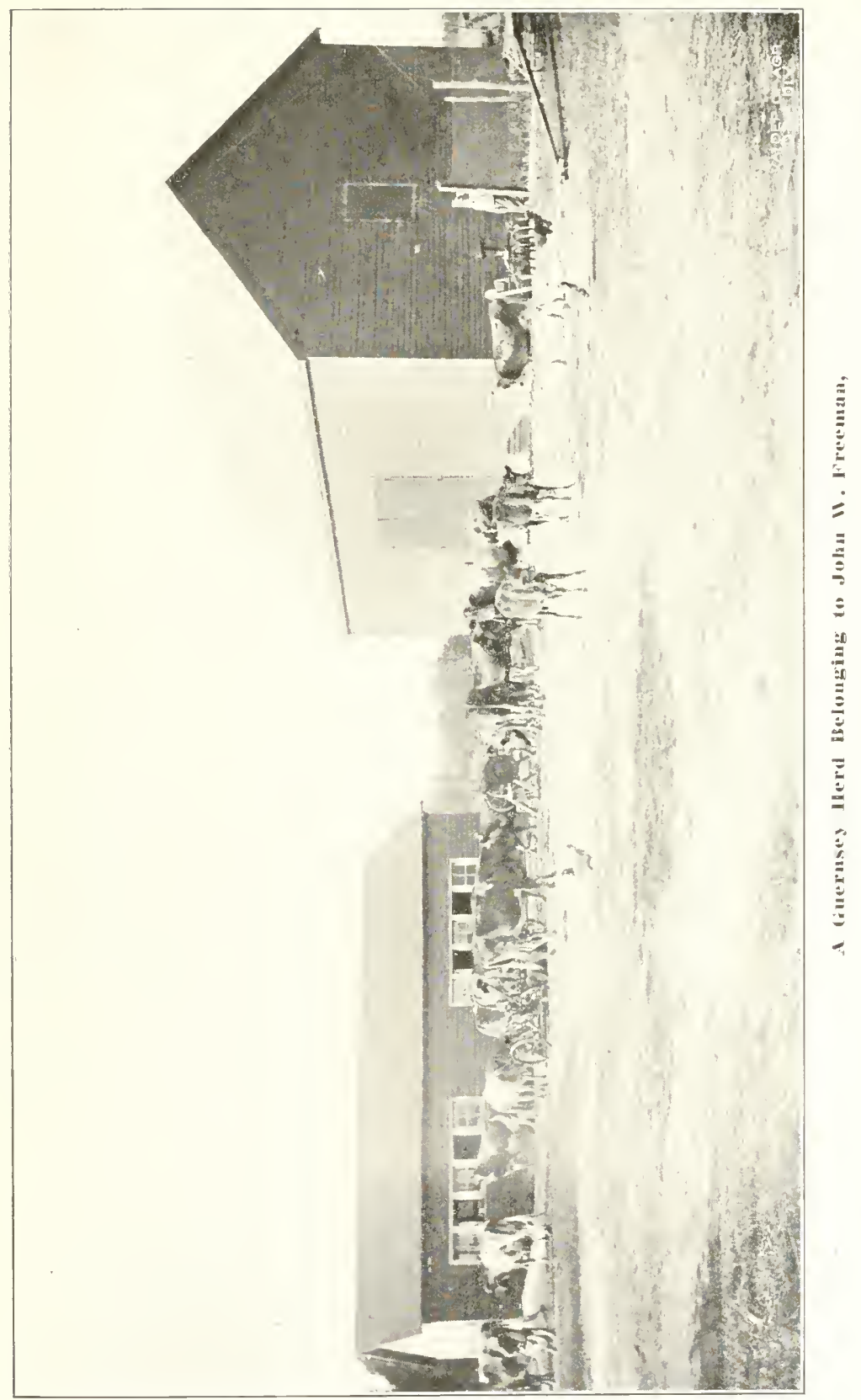

Page Fifteen 


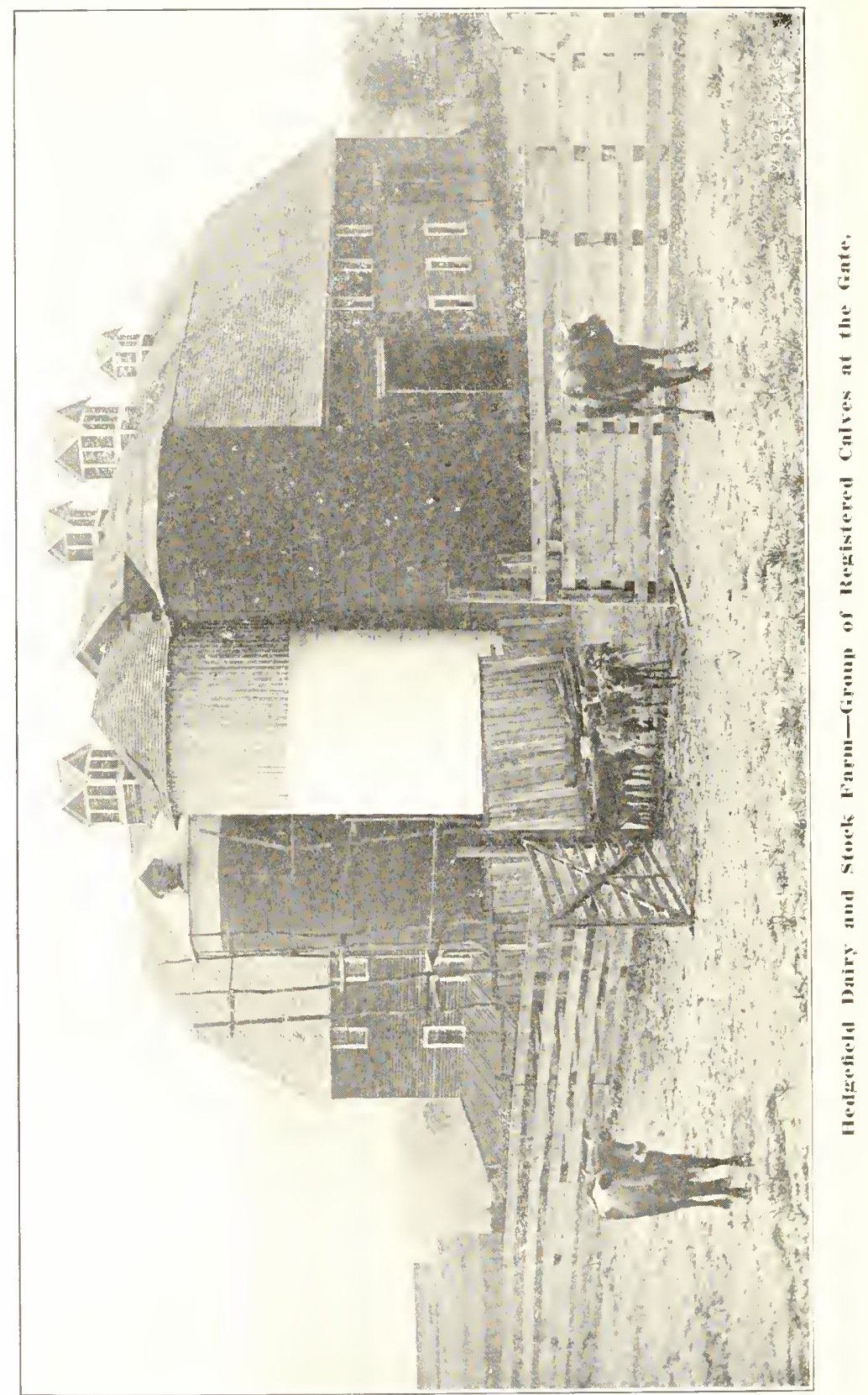

Page Sirteen 


\section{Ten Reasons Why a Dairy Farm in Virginia Pays Better Than in Any Other State}

\section{CLIMATE.}

Virginia has nover hard a hlizzard, a crelone ol an earthquake. The winters are long conough to give the farmer a chance to ent ioe from his own fome, and to kill ont moxions inserts. They areso short as to malie grazing warticable for nine months in the year.

\section{Short and Mild Winters.}

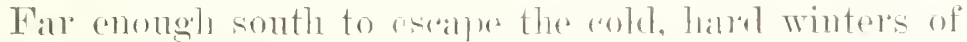

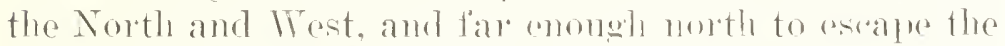
torrid heat of the South, Tirginia has a tomporatmo wo]l

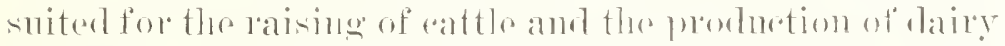

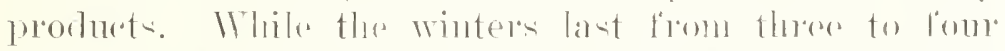
montlss, the temperature seldom falls bolow ten deraress above zero, and there are fer days that it does bot lise

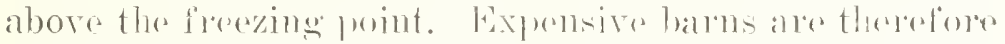

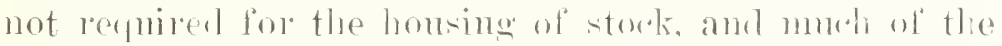

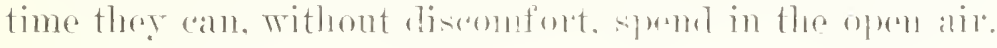

\section{Long Grazing Season.}

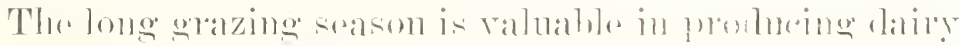

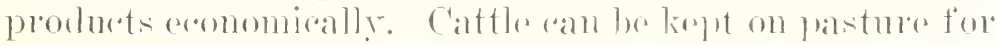
some time after frost has destroyed the pastmes of less

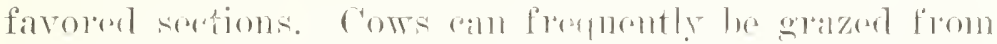

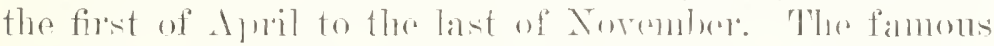

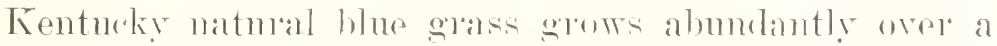

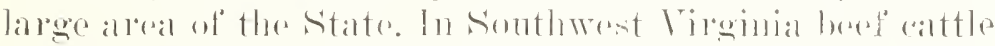

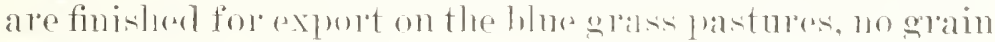
being forl. 


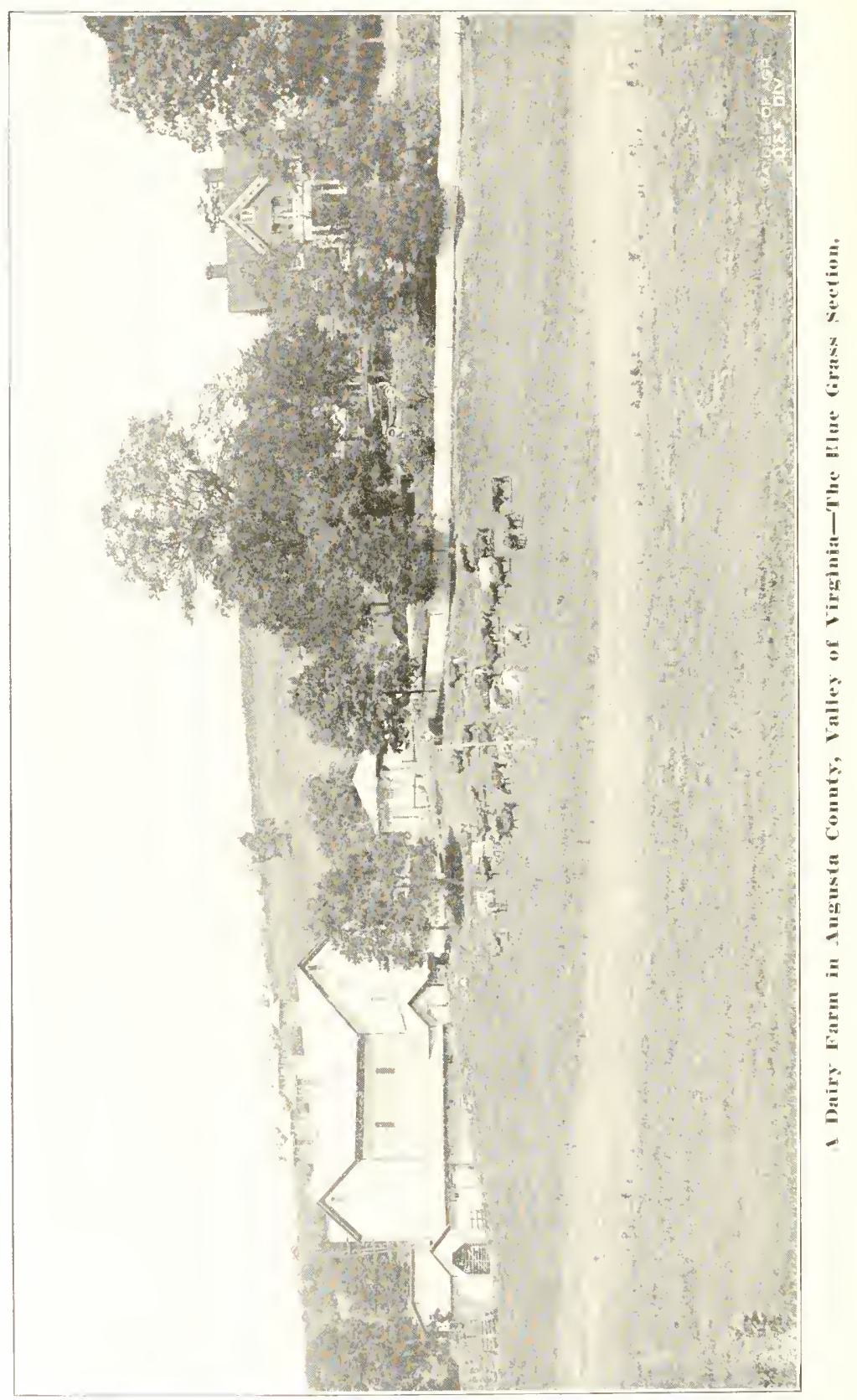

Puge Eightern 


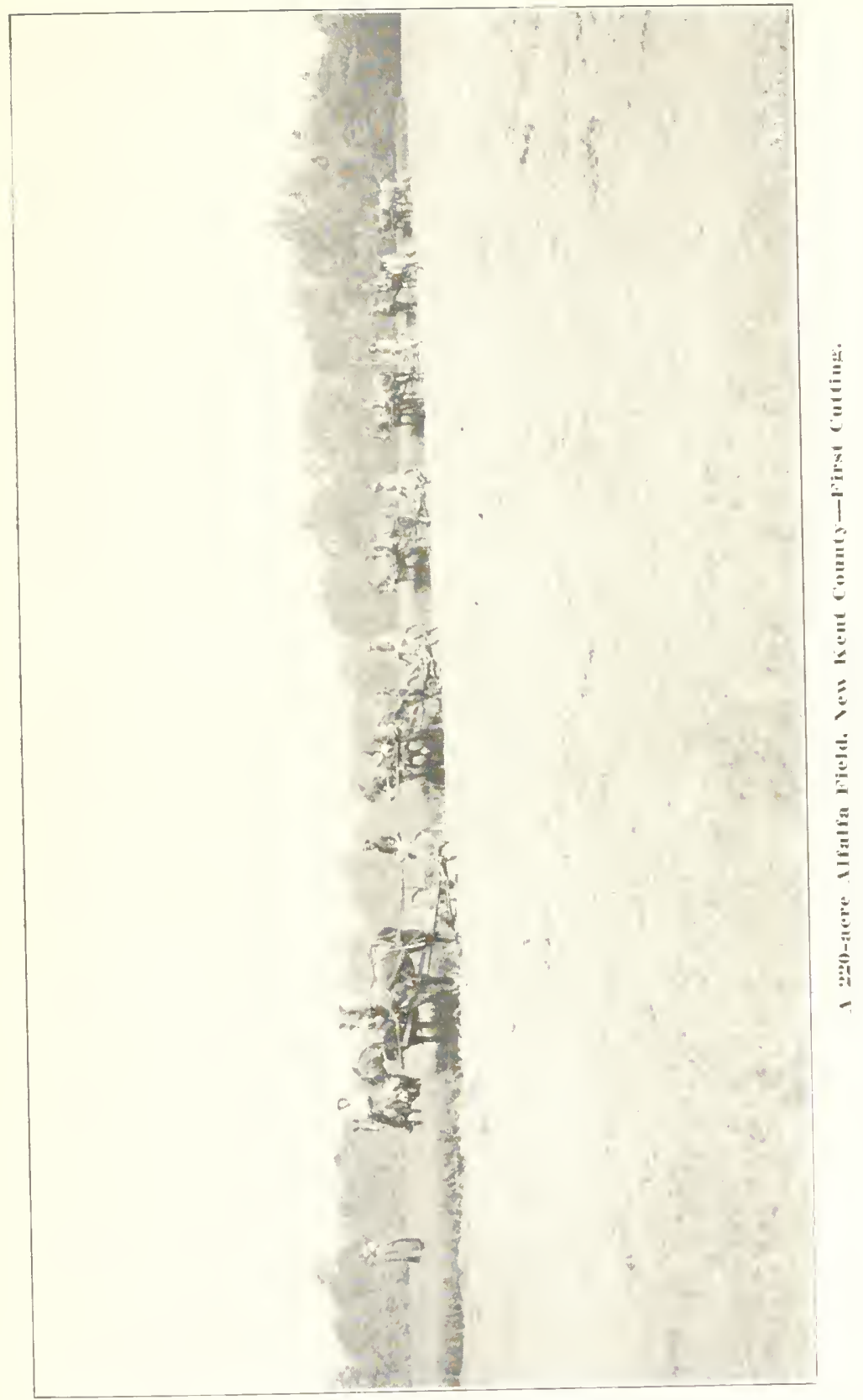

Page Ninteen 


\section{WATER SUPPLY.}

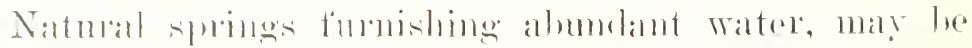
found on most tarms in Vireinia, withont affort, for the cattle, and - smply ling with the lolp of simple and inexpen-

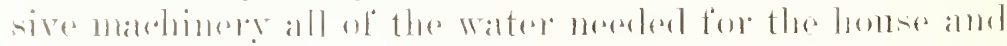

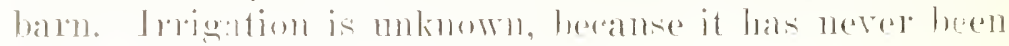

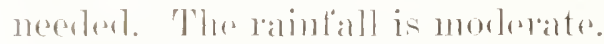

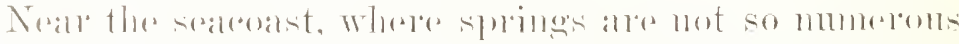

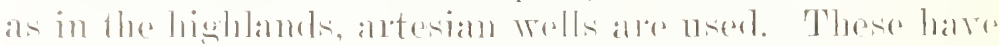

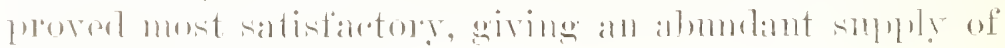
[xecallant flowine water.

\section{LOW-PRICED LANDS.}

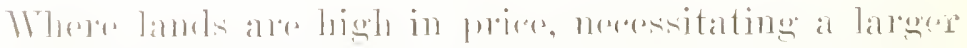

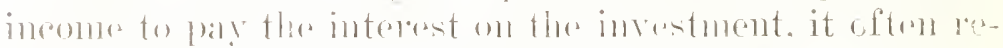

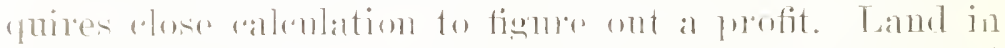
Tirginia, which is in antivalion, and that will respond

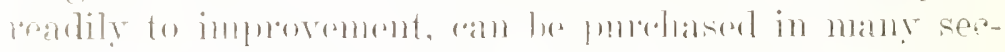
tions as low as a

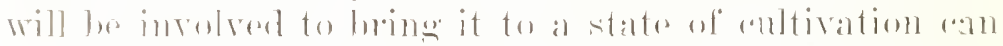

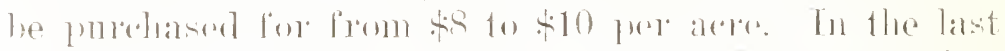

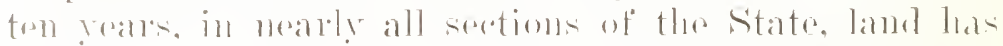
more than dombles in value, lut the pures is still small, and is asperoblly inviting as an imrostmont.

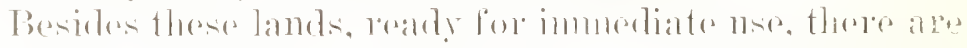

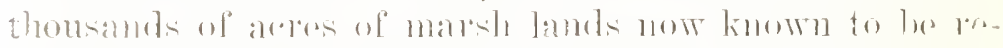
damalule at a cost which. in five yalle, will bring anor-

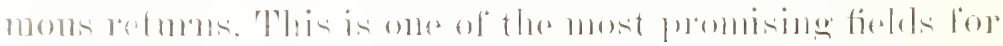

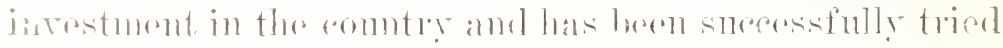

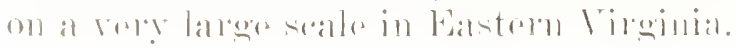

\section{SOIL.}

Tho stato is divided natmally into the low-lyinge lands

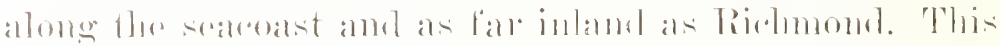
section is known as the Tirlewatre rewems the Piedmont eomes mext, lying, as its name implies, at the foot of the 
Blue Ridge; bevomt the Blue Rirlge stretelues the range of the Alleghanios, and between those two ranges bies

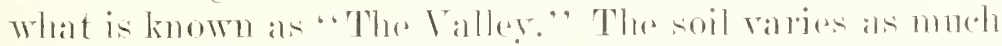
as the chararter of the comber. In 'Tidewater Virginia ale plains with responsive and warm soil suitable for

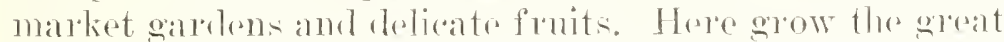

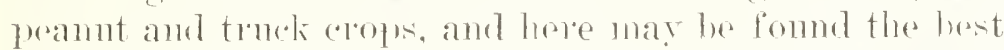
examples of intensive aglienlture in the Lnited statrs.

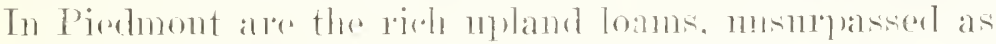

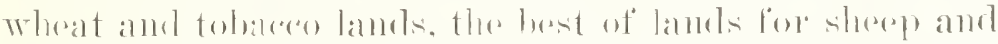

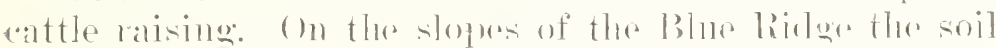

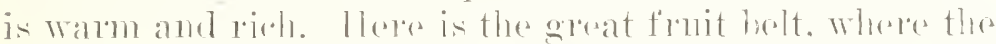
apples grown liave mate an intermational repulation for

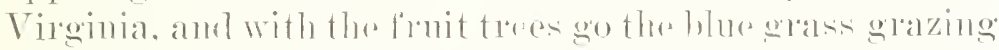
farms. 'Ther Vallor, with its heary alay amel limestomo, is the home of the lamome hlue glass. Soils. suitod to all

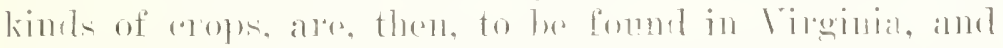
with any or all of them the dairy and rattle hosiness is a naturat and profitalubarlinnet.

\section{CHEAP FEEDS.}

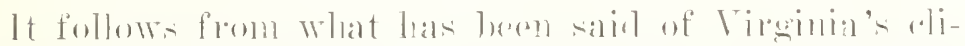

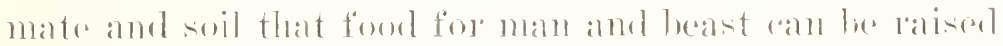
at a minimmun rost. ('orn is king in Tirginia. No state

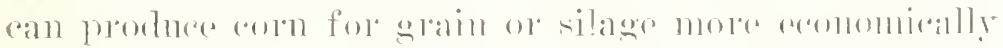

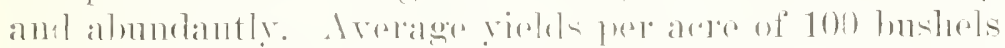
of "orne or twenty fors of silage are rommon. (lwing to

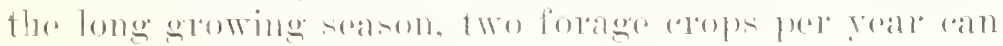
be glown with guat porit.

\section{Crimson Clover.}

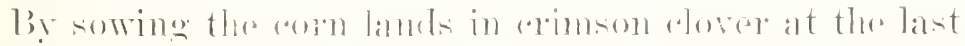
working of the rorn, this rop contes in the eally spring

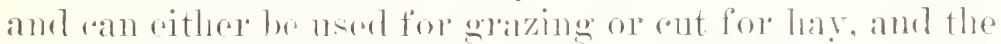
lamel again planted in rorn or some other crop. Crimson rover is not only a soorl fored for dairy rows. lunt also al 


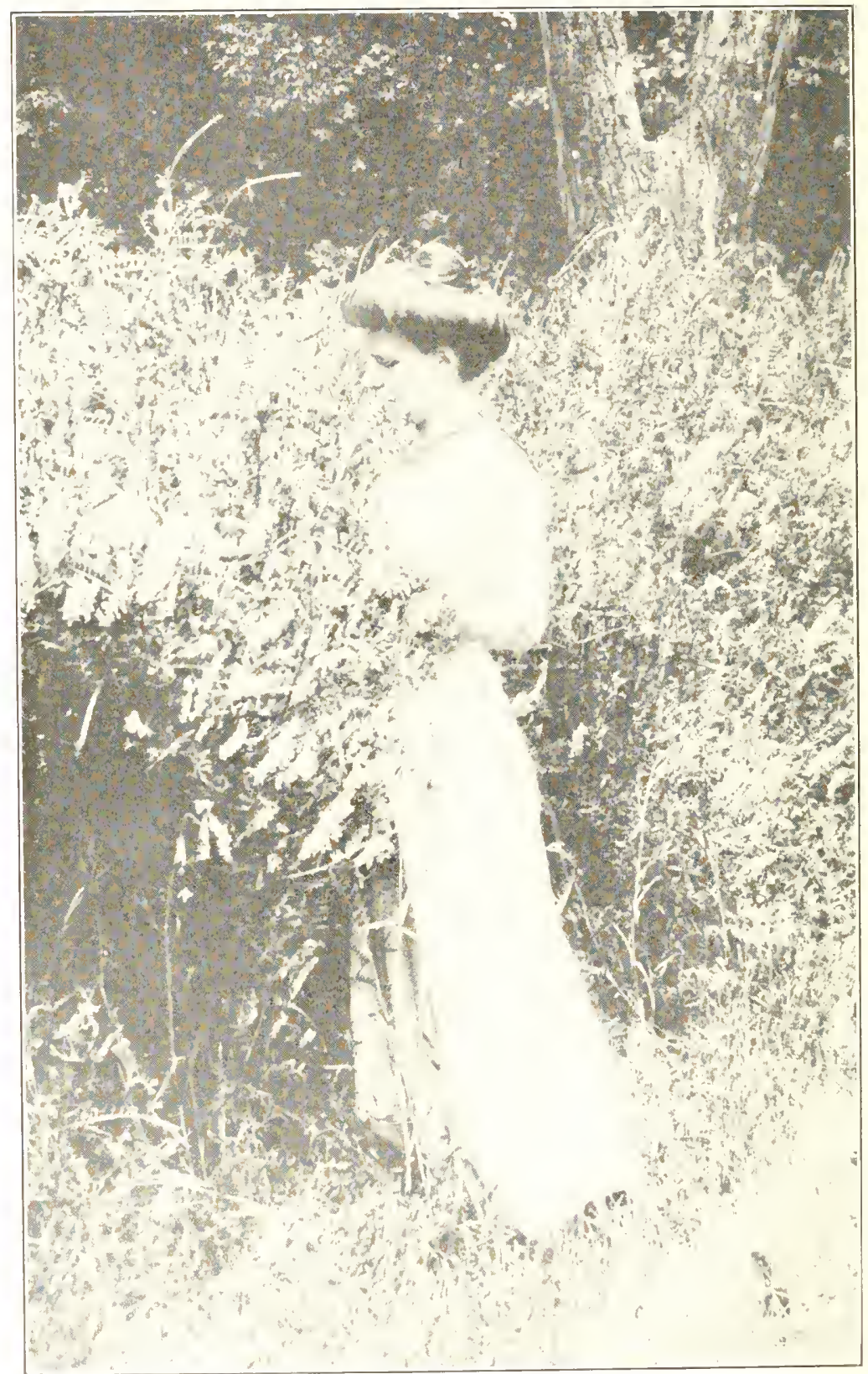

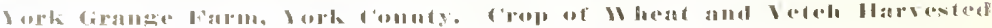

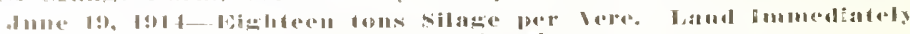

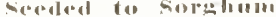




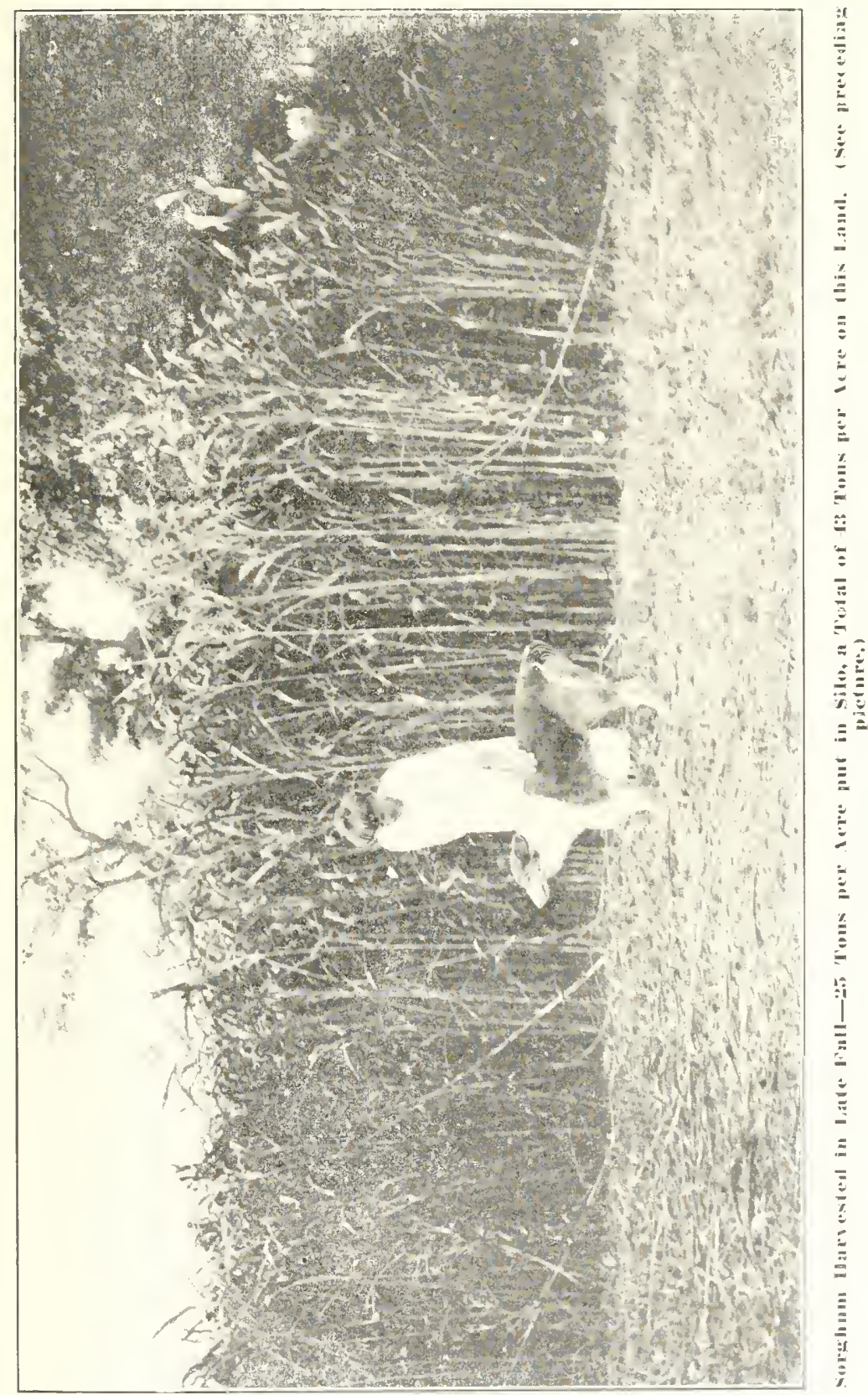

Patu: Treentu-tile 


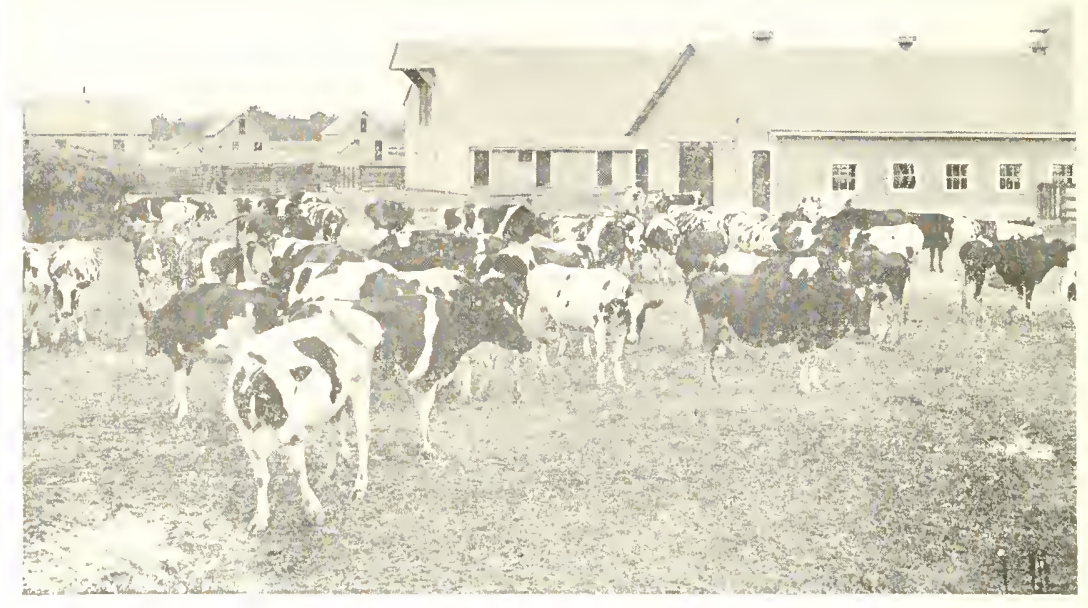

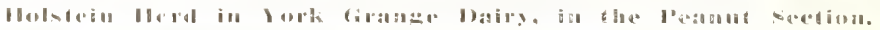

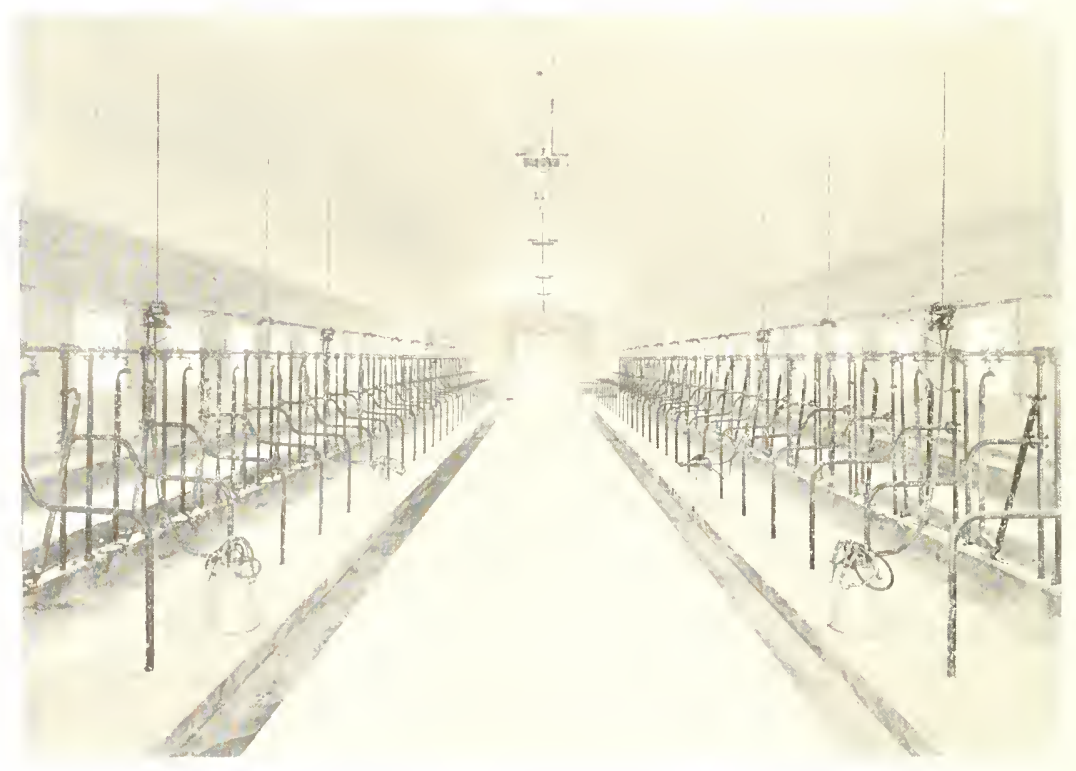

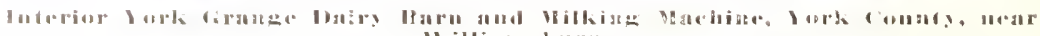
II illiatushlol,

Prifr Tuentu-four 


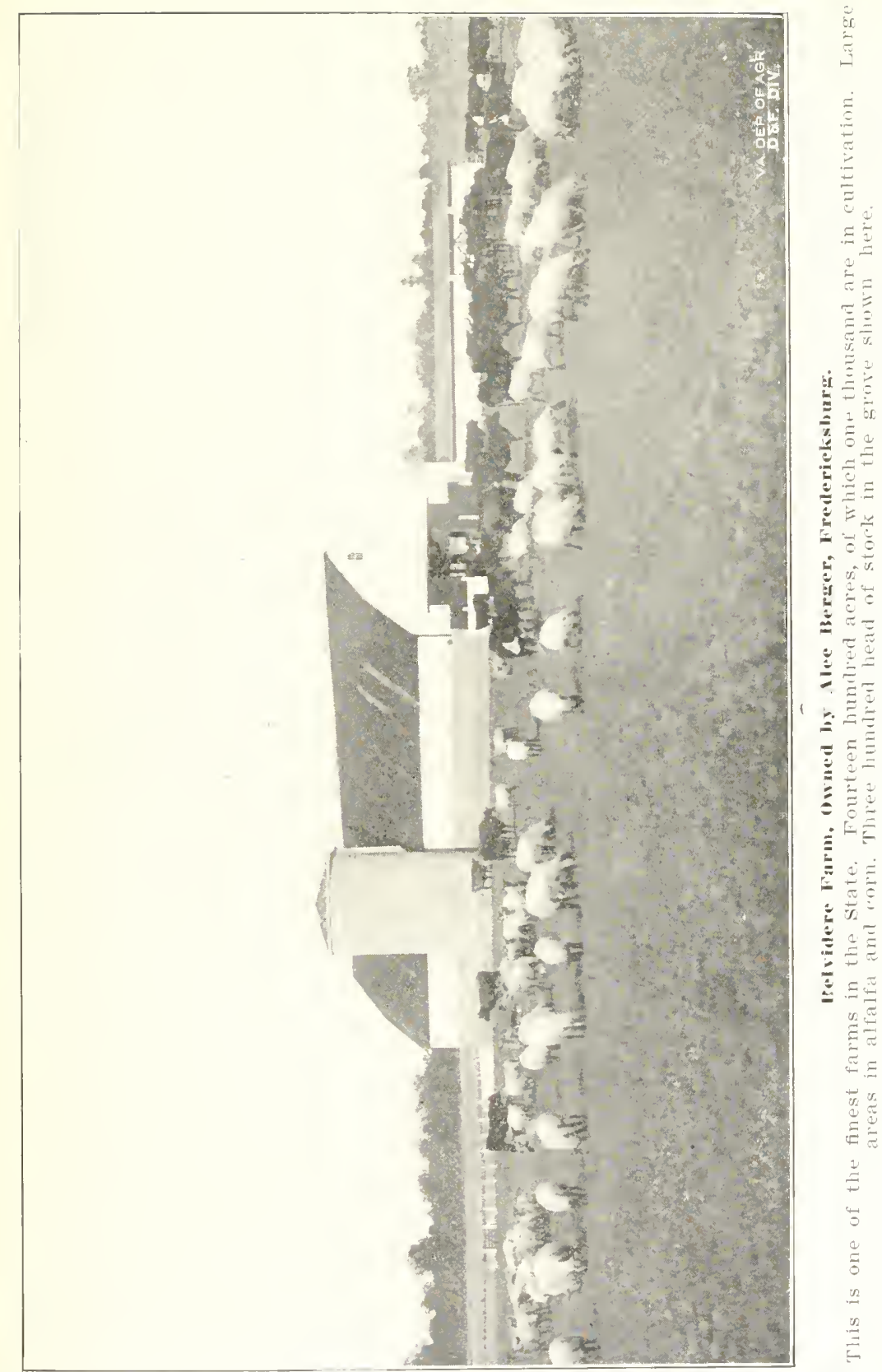




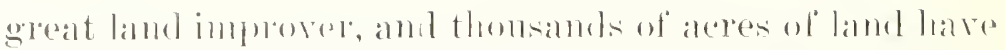
been impored hy the me of this most valuable legmme,

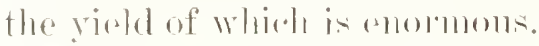

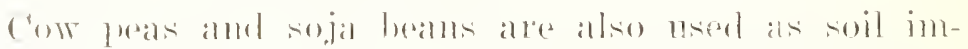

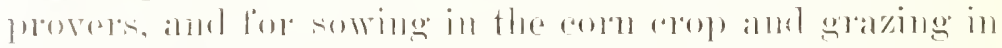

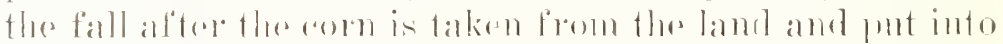

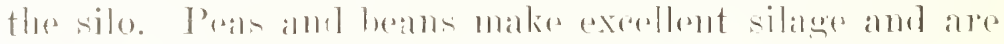
la logely usal in Virginia for this pumpose.

\section{Alfalfa.}

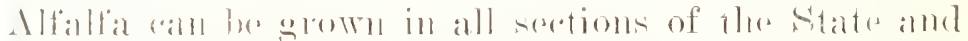

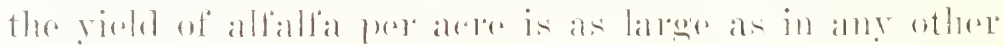
Nitate, with the posilile sxoption of the imigated sectioms of tho Woxt. This is a renp that the farmers are

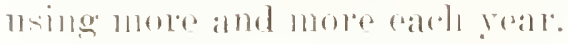

\section{Other Crops.}

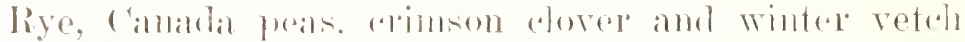
are crope that, in their ombre, come to matmity in the

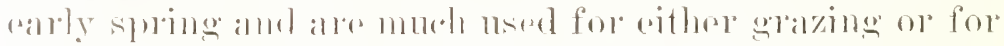

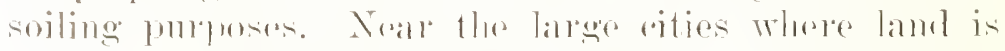

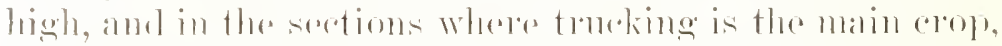

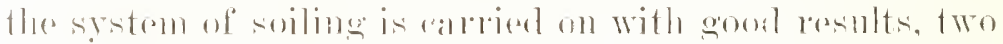

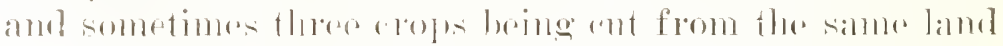

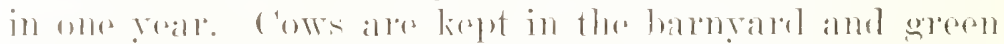

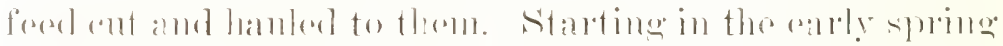

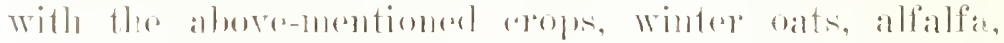

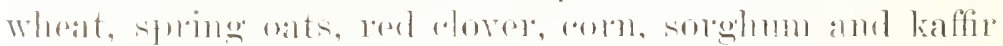

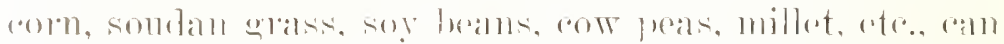
hes

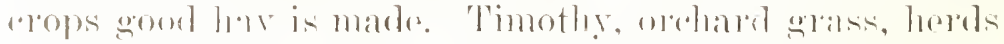

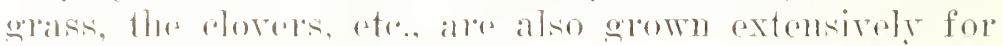

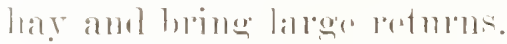

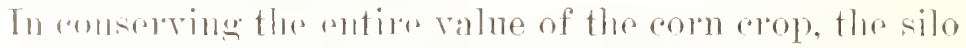

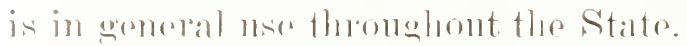

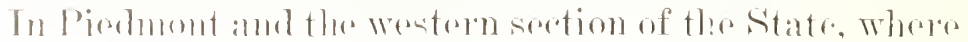




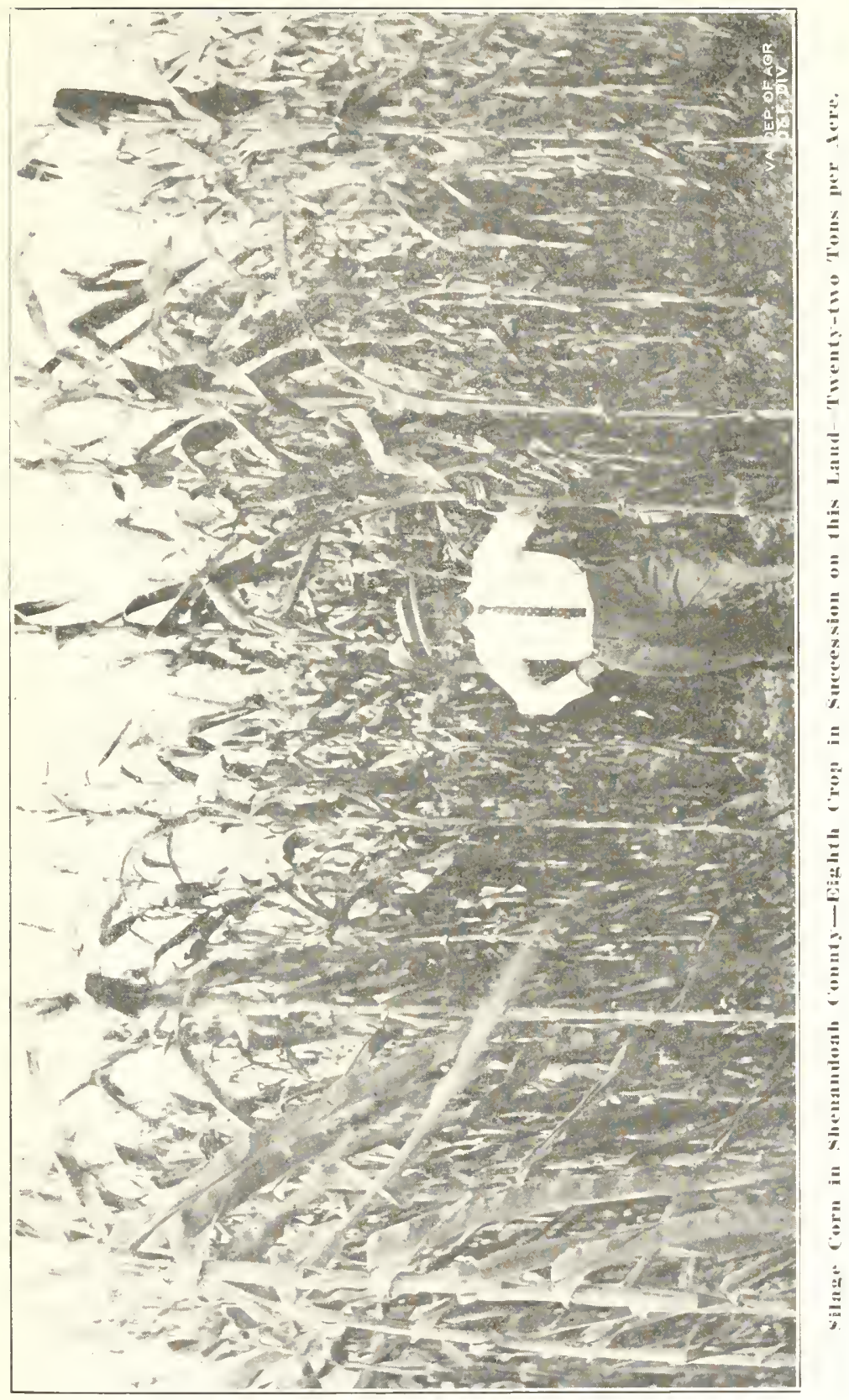

Puge Twenty-seven 

the blue grass is a natural product amel where in the past export beef has been raised, fhose farmers that havo taken mp the dairy work have demomstrated that milk and he produced perhaps more economically than ia any part of the Enion. On those l, he glass farms, allowing a fair price for the grazing of the stork, and for all labor inrolverle it has beren demomstrated that milk wall be produced at a rost as low as six eente per gallon.

While in the asstern section natural hlue grass does not thrive as it does in the momntains and hills of the western and central parts of the state, yet these sortions. which are not so high above the sea level, are asporially adapted for the raising of leguminons arops of all kinds, and here the nearness to the seaboard makes the marketing of early garden truck especially profitable.

\section{PRICE OF LUMBER.}

Tirginia is one of the fow States that still has large areas of growing timber and the low price of lmmber. compared with the prices paid in ofleer states, offers indneement to the farmer to build barns and silos.

In the last few years thomsands of silos have been put mip in the State, and many of these lave been home-made, and in hundreds of ases the lumber has been supplied from the farm on which the silo was erected.

\section{DEMAND FOR DAIRY COWS.}

There is a comstant demand throughout the Sonth for good dairy cows. During the past few years large numhers of dairy cows have been hronght in from the North and West, the demand being moln greater than rould he smpplied hy the breeders of the State. The dairyman using a pure-bred sire and grading up his berel will find a ready sale for all of his smplus stork. This demand has alleady created a smply, and from the standpoint of breeding and production Virginia can show some of the 


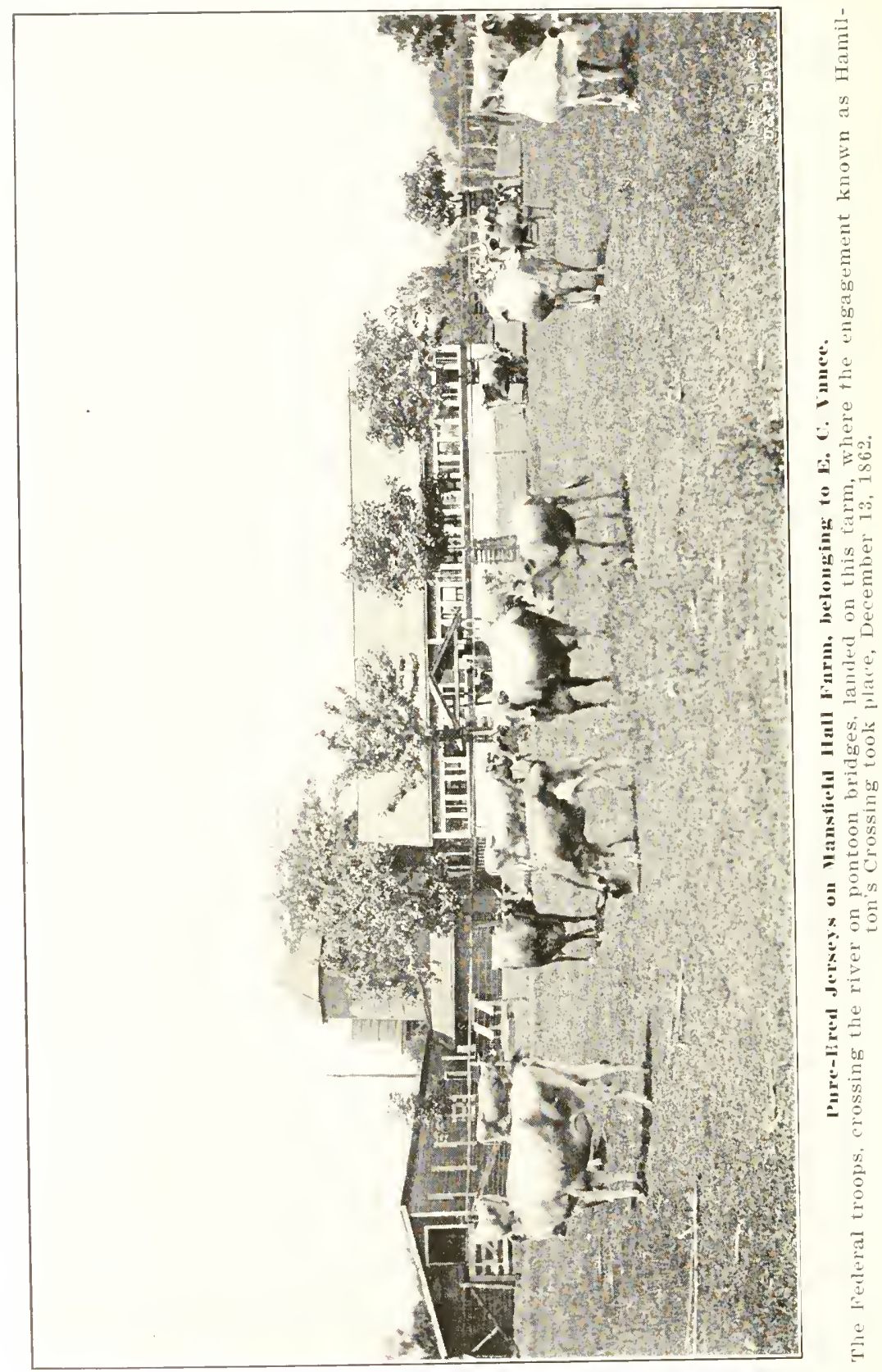

Pare Thirty 


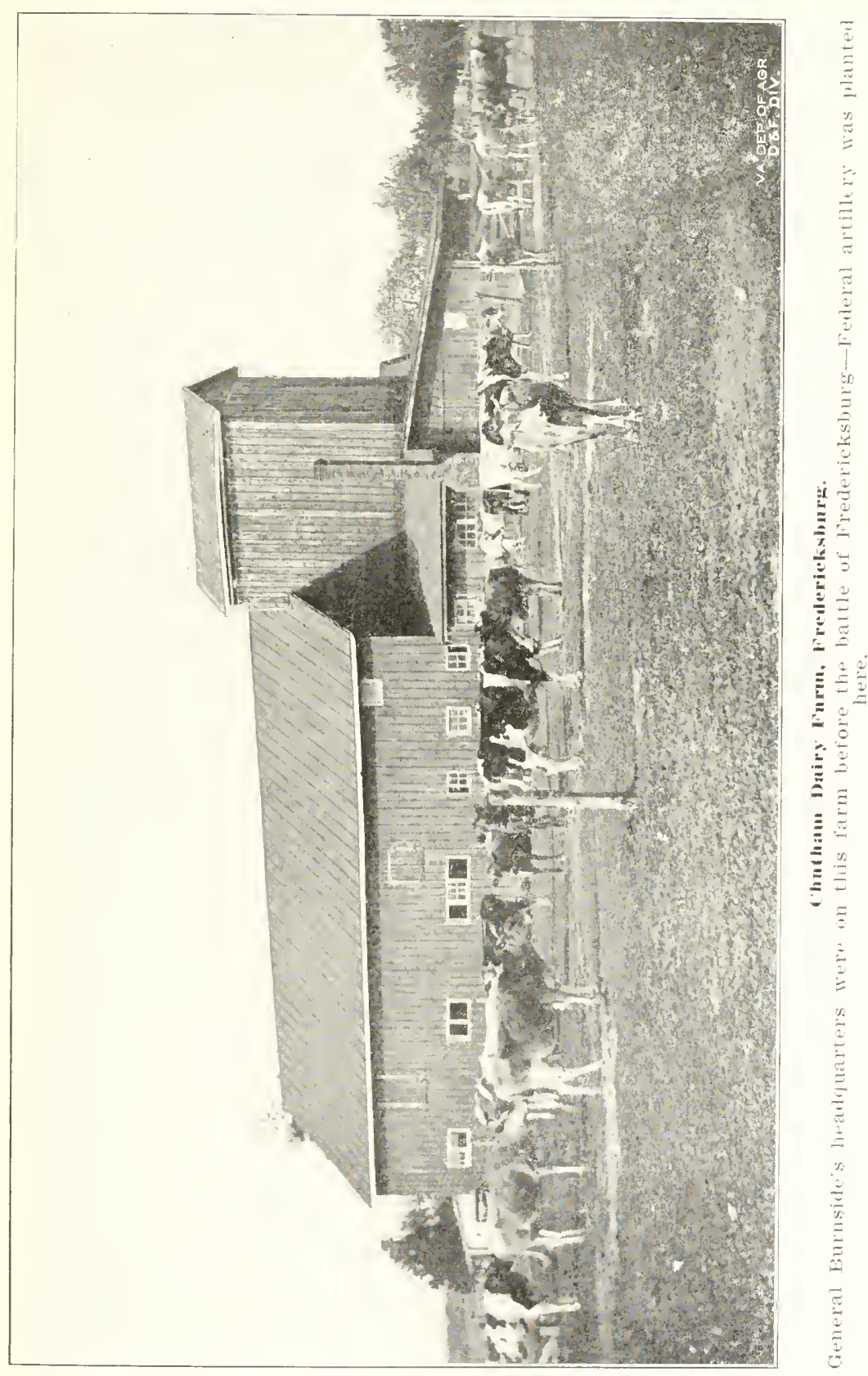

Page Thirty-one 


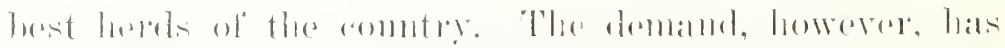

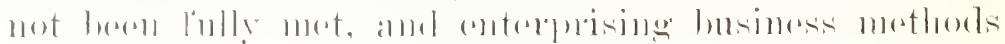

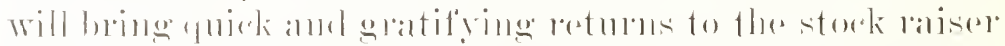

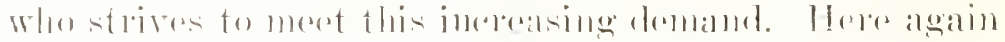

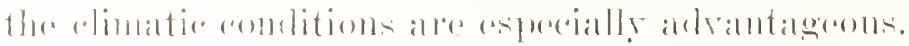

\section{TRANSPORTATION.}

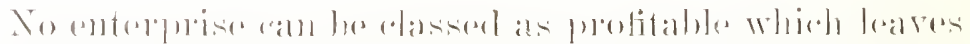

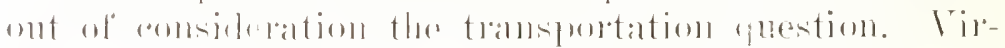

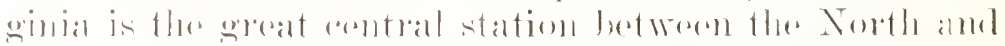

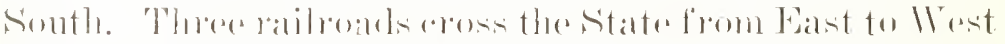

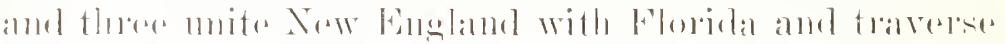

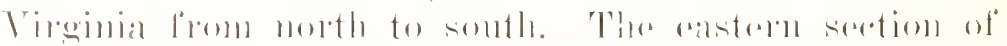

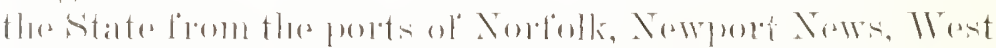

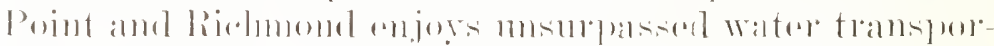

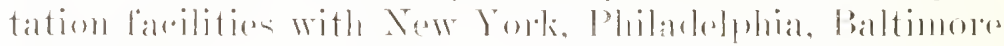

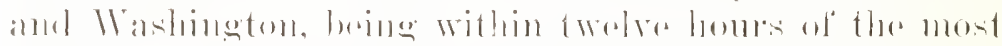

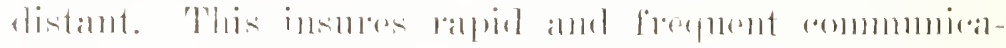

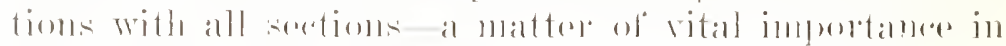

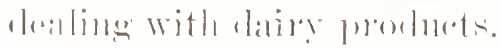

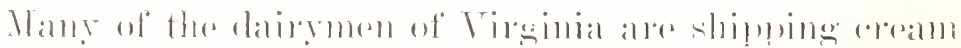

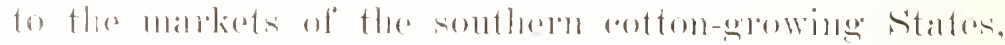

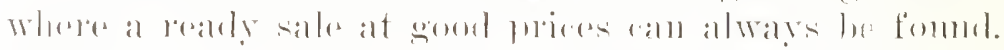

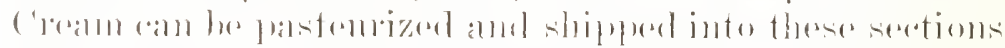

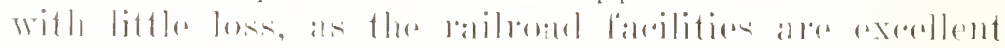

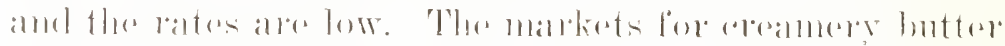

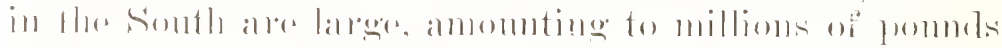

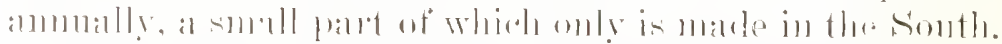

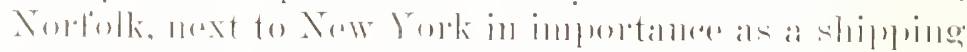

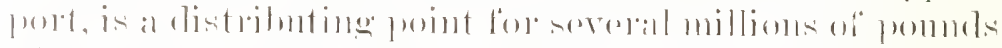

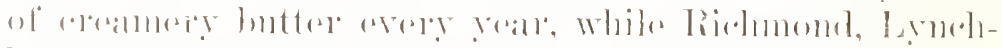

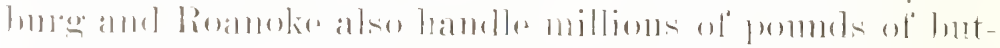

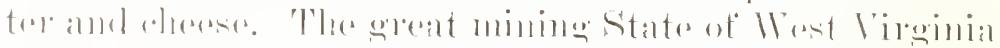

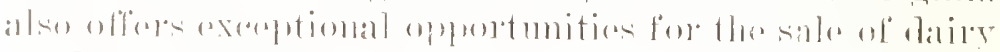

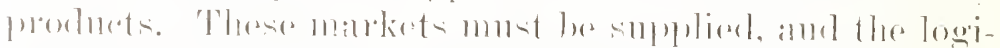

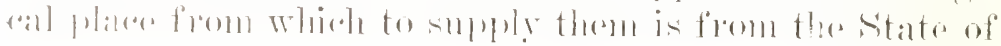




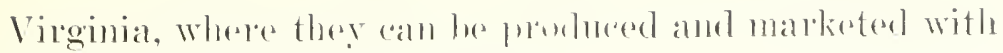
least cost and gleatest facility.

\section{UNLIMITED AND UNEXCELLED IMARKETS.}

In 1914, of twentr-uine citiess locaterl in all parts of the

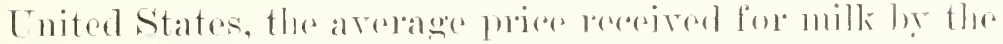

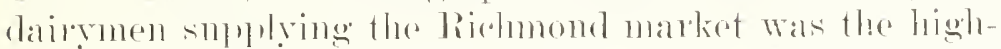
est, while Washington, 1). ('., eame next. Fivo humberl

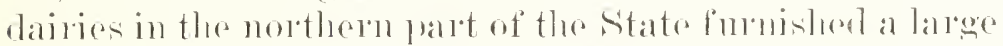
portion of the mille sold in Washington. Ridhmond is smp.

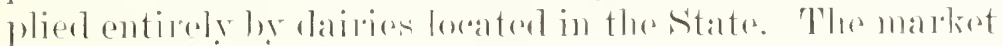
for ereamery buttre and dhese in Virginia, amd the six States immerliately south, is practically molimited. None of these provide more thath a rery small pere rent. of the

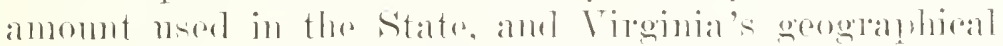

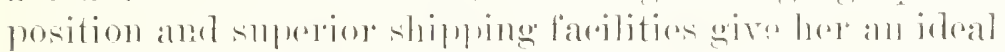

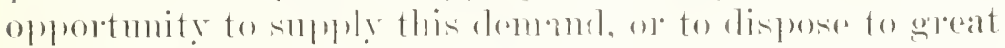

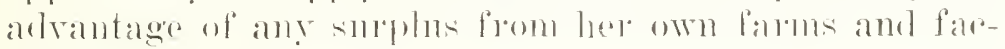
tories.

\subsection{EXPERT AID.}

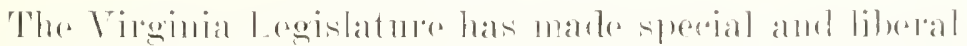

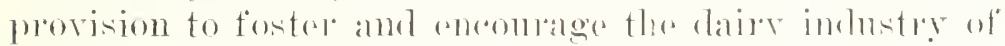
the State, and the Wairy and Food l)ivision of the State

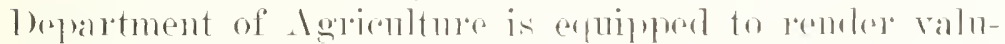

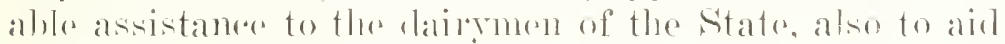
prospertive dairymen in every possiblo way. They are

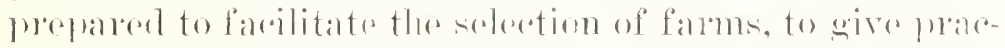

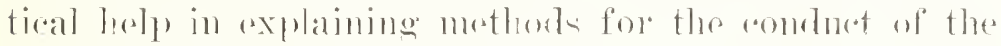

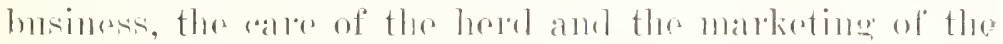

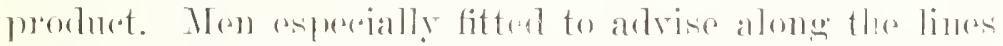

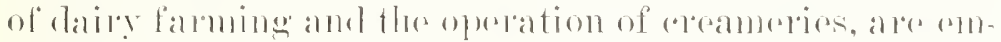

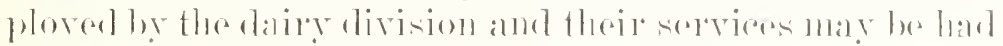
withont whare be any one asking for them.

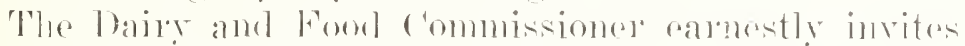

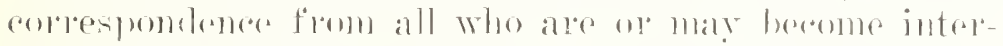

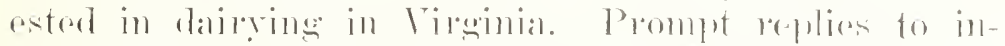

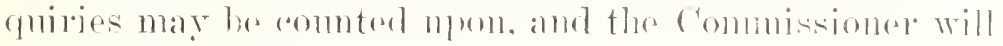

Page Thith-thite 


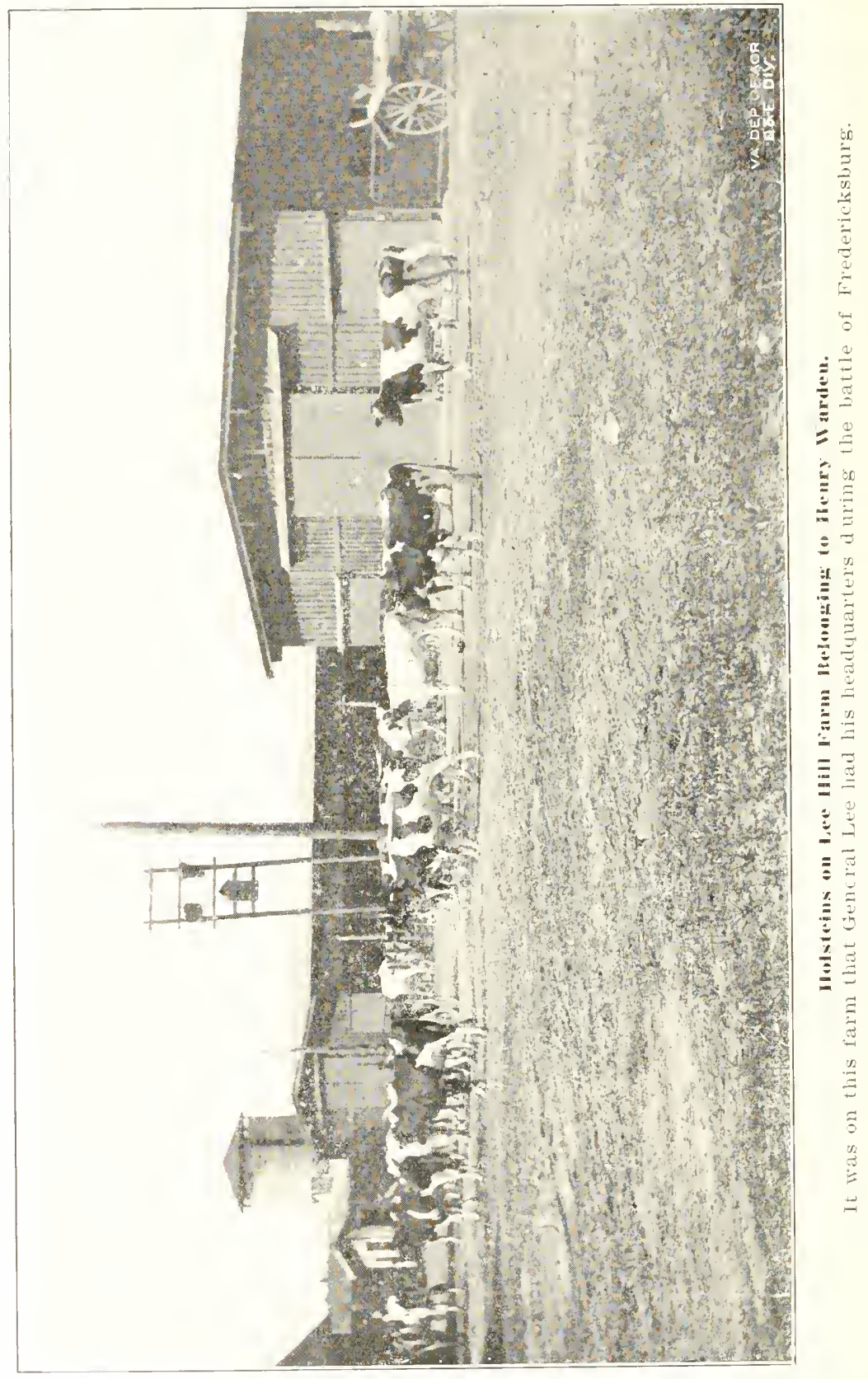

Paye Thisty-four 


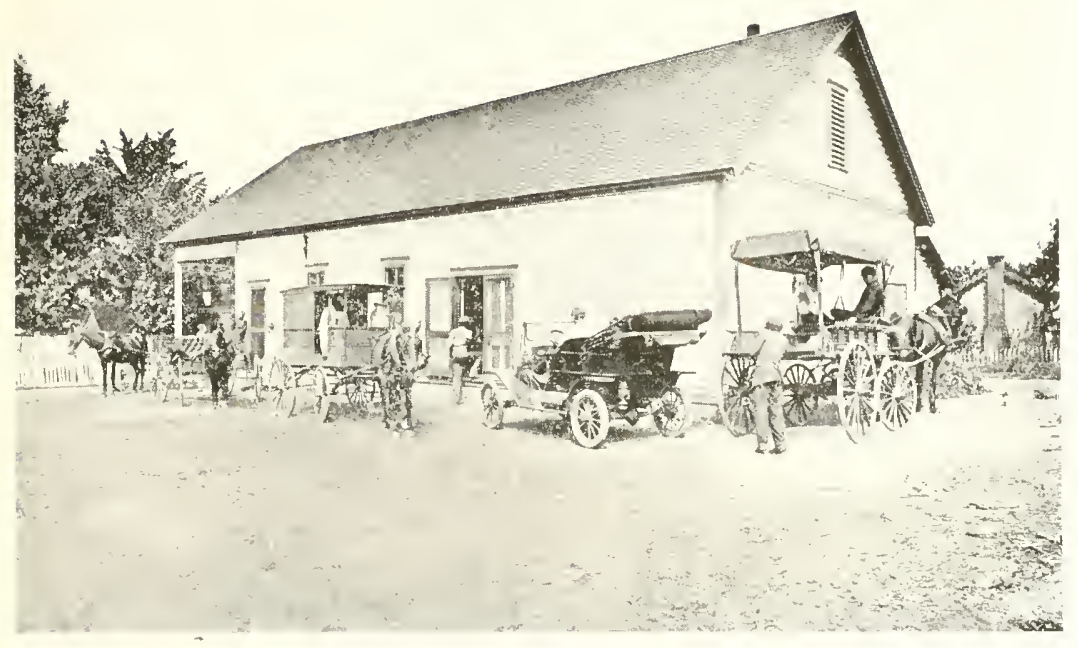

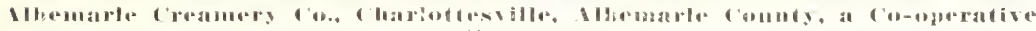

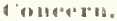

This is near the [roivrsity of Virginia, one of the most lentutiful p]ares in the state, famous for its fruit eroming as well as for the steit of learlling folnded hy Thomas Jufferson.

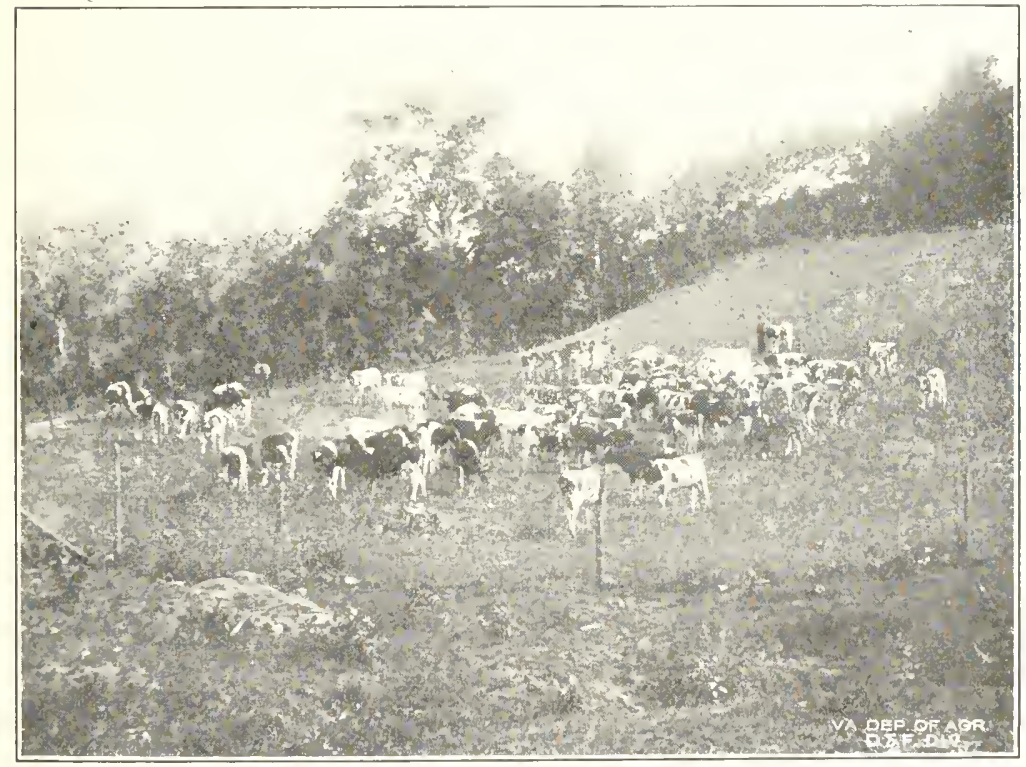

Page Thirty-five

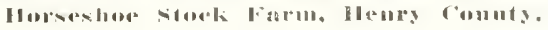




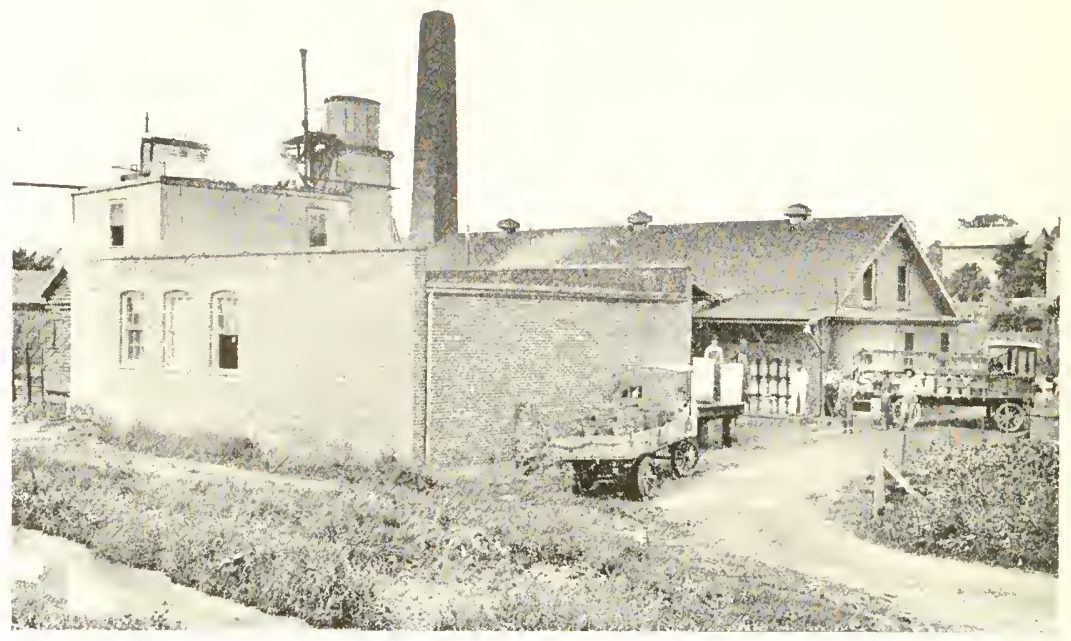

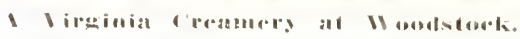

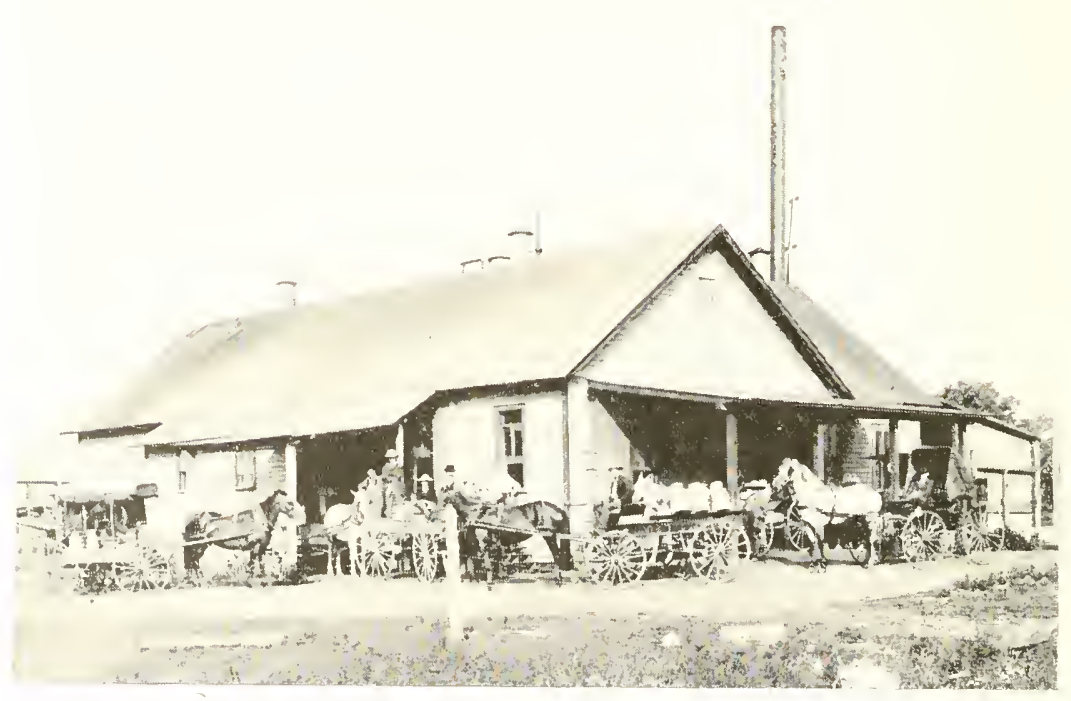

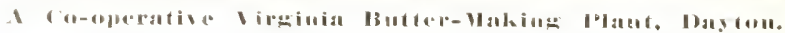

Page Thity-six 


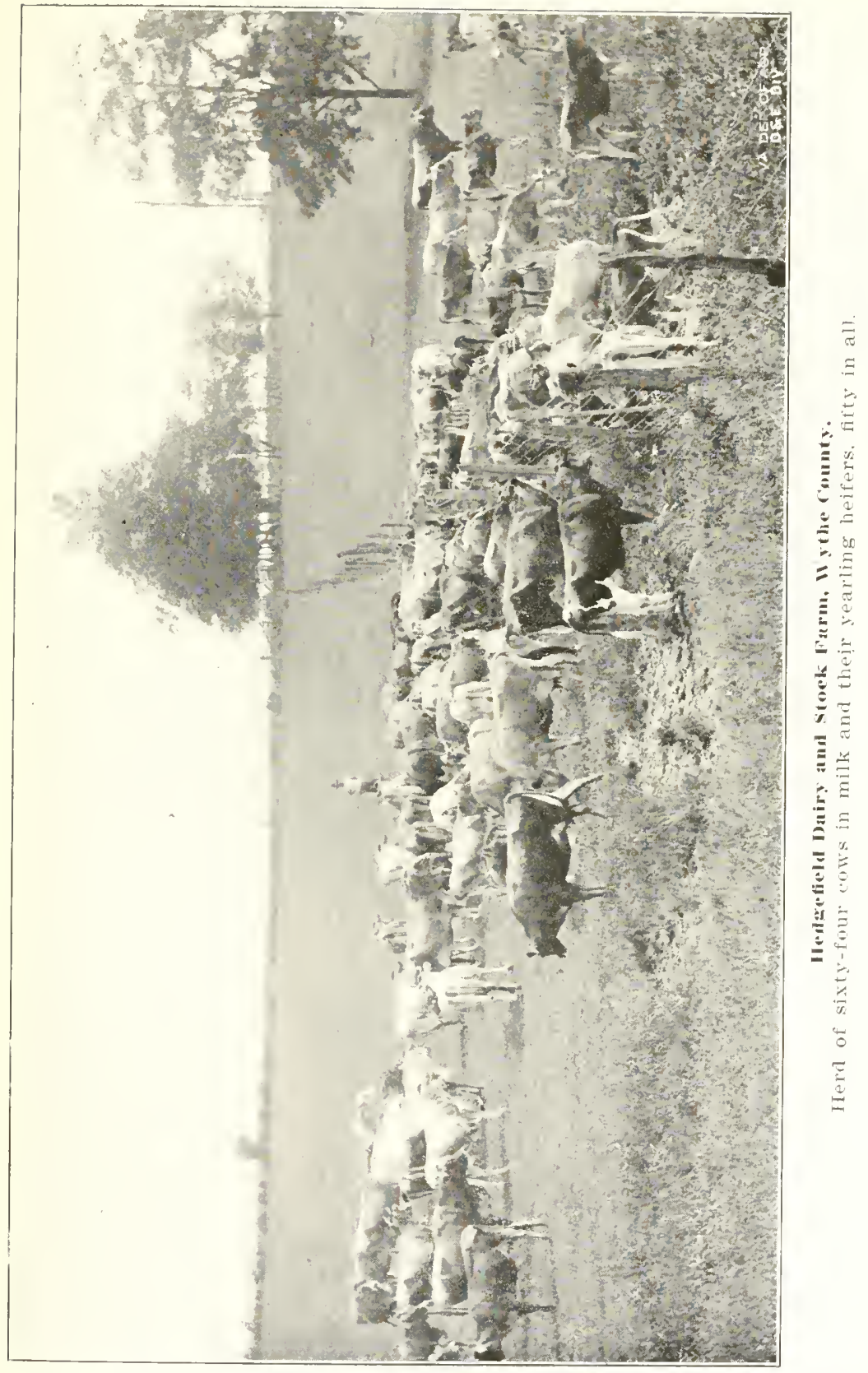

Page Thirty-seven 


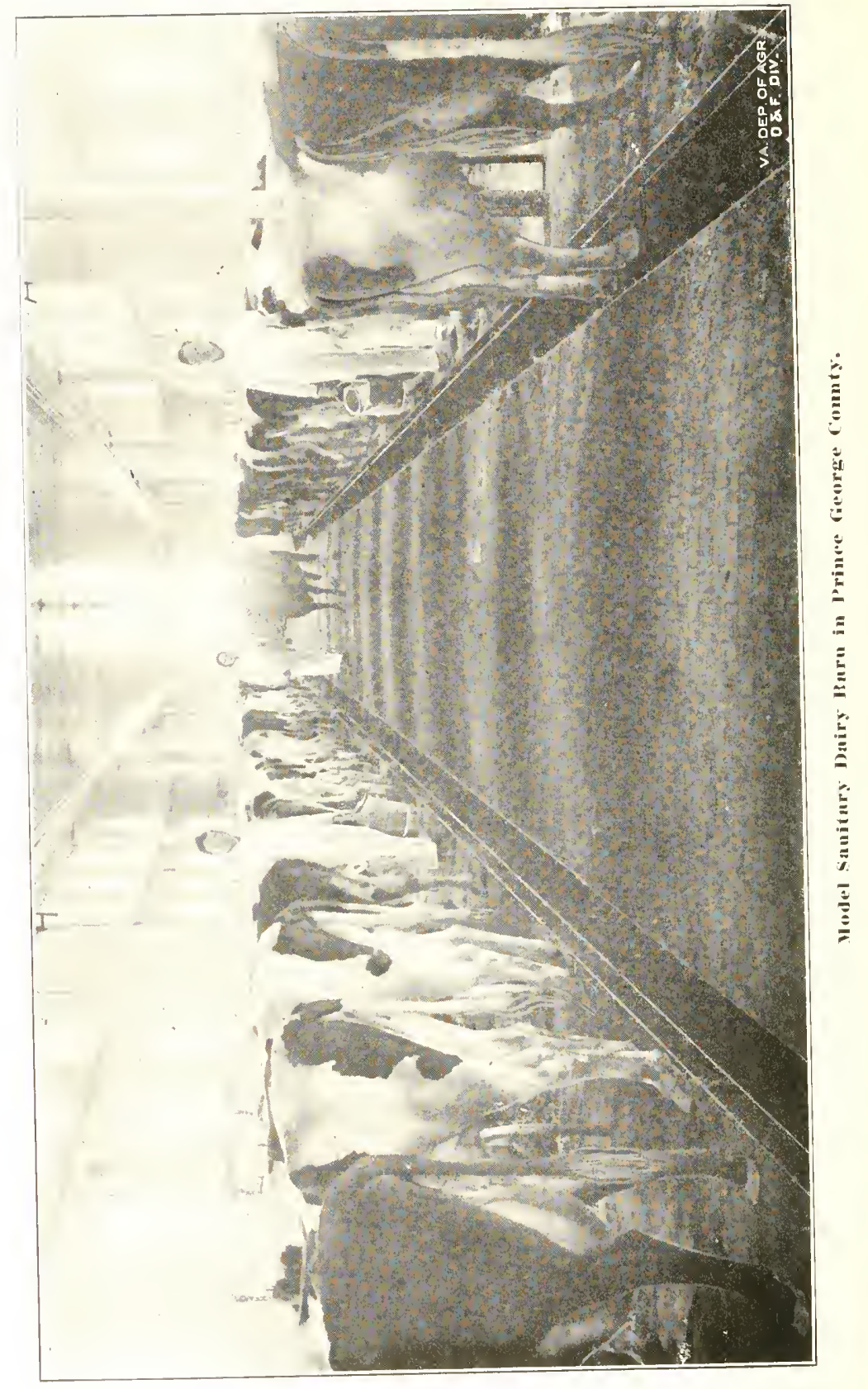

Puge Thirty-eight 


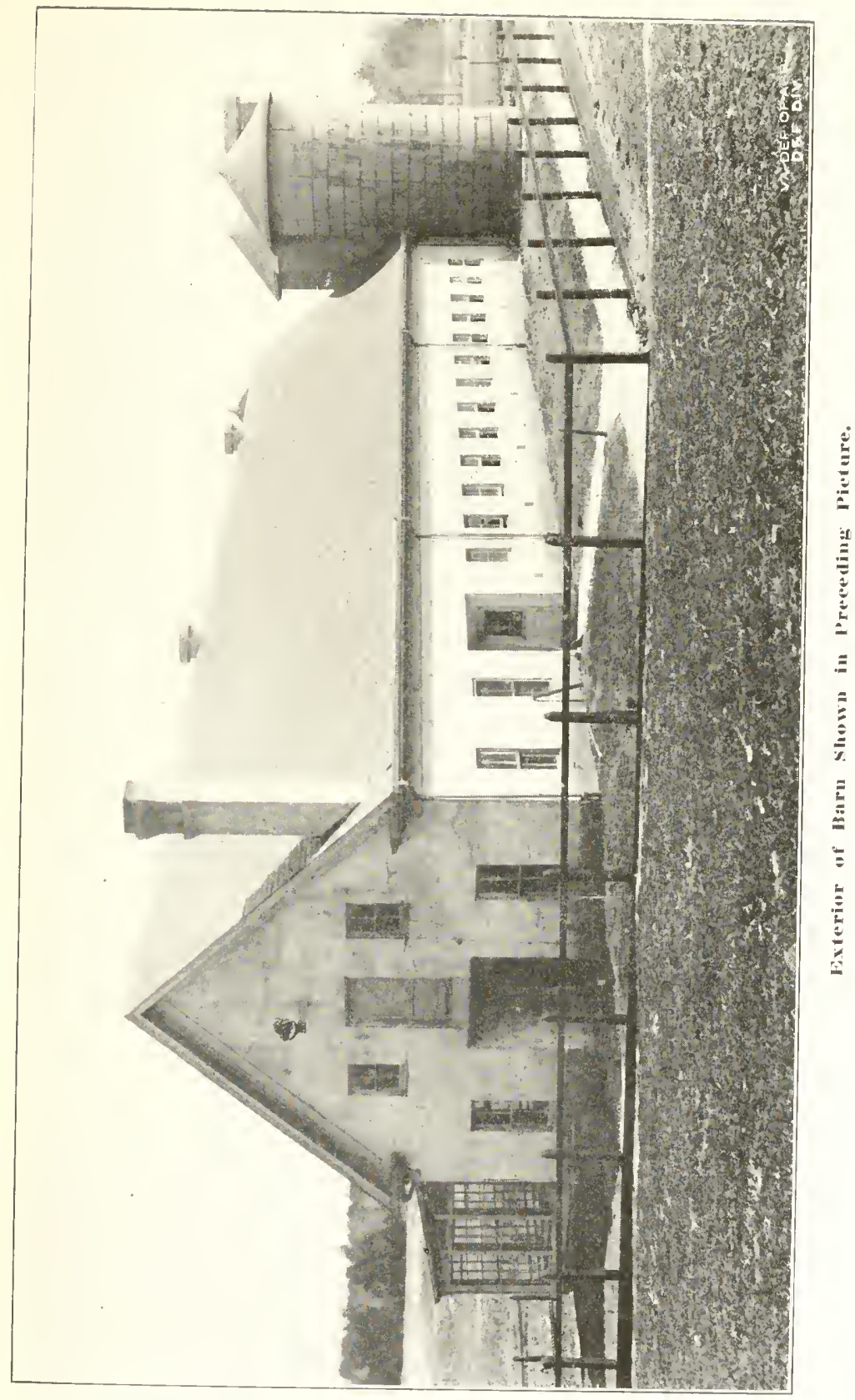

Page Thirty-nine 
not only furnish losired information, hut will also personally assist prospertive investors in finding suitable localioms, and in helpring throm to stat right and to keep right.

\section{SUMIMARY}

A man whe is looking for great pessibilities in thes dairy husiness most kene in mind these features:

1. Ite mexats a enod relimiate.

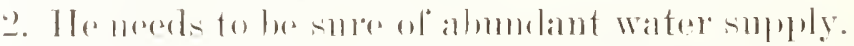

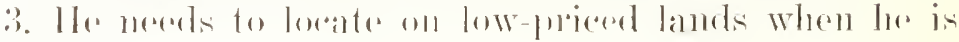
starting.

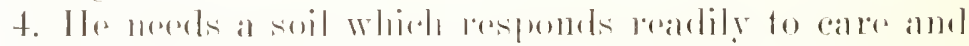
lobles the imporovement.

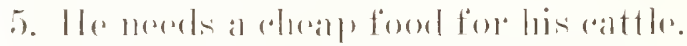

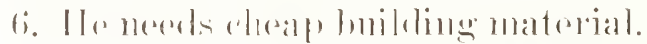

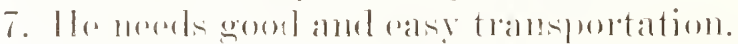

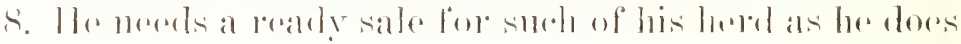
mot desider to kaspe.

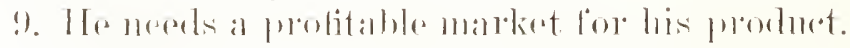

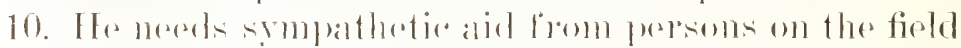

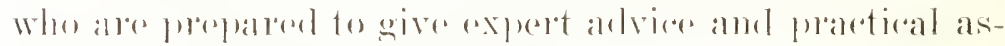

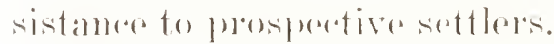

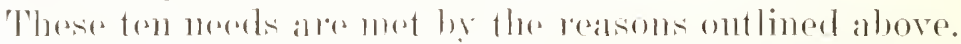
Il you lave any dombts on the sulderet they call be easily solved by writing to Benj. L. P'mooll. Dariry and Food

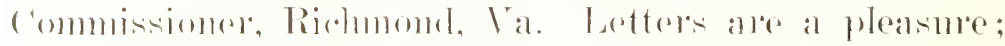

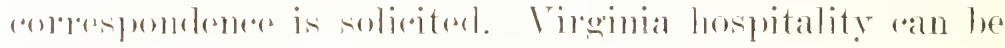
shown "rout through the mails. 
